\title{
Grassland Ecosystem Management Plan for the Oak Ridge Reservation
}

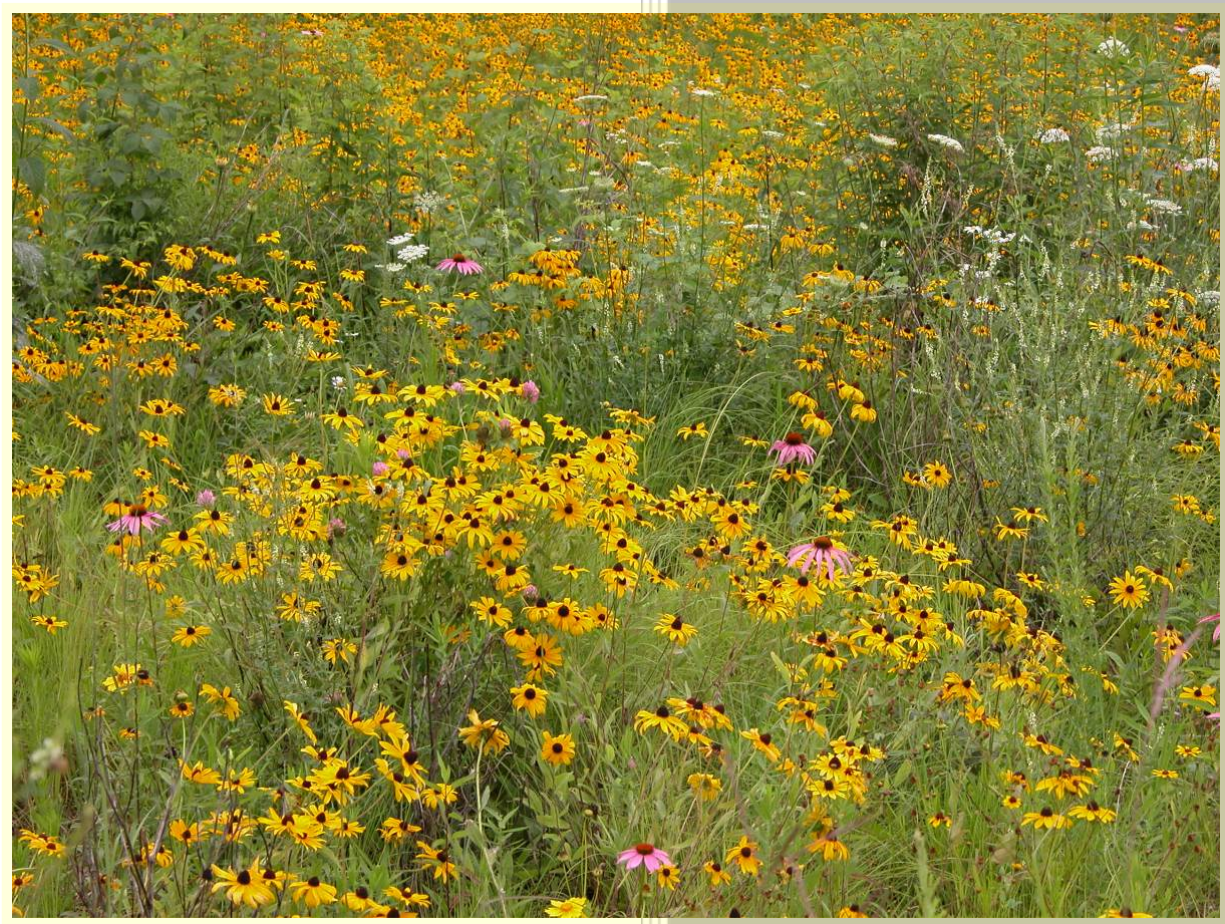

Approved for public release. Distribution is unlimited. 


\title{
DOCUMENT AVAILABILITY
}

Reports produced after January 1, 1996, are generally available free via US Department of Energy (DOE) SciTech Connect.

Website http://www.osti.gov/scitech/

Reports produced before January 1, 1996, may be purchased by members of the public from the following source:

\author{
National Technical Information Service \\ 5285 Port Royal Road \\ Springfield, VA 22161 \\ Telephone 703-605-6000 (1-800-553-6847) \\ TDD 703-487-4639 \\ Fax 703-605-6900 \\ E-mail info@ntis.gov \\ Website http://www.ntis.gov/help/ordermethods.aspx
}

Reports are available to DOE employees, DOE contractors, Energy Technology Data Exchange representatives, and International Nuclear Information System representatives from the following source:

Office of Scientific and Technical Information

PO Box 62

Oak Ridge, TN 37831

Telephone 865-576-8401

Fax 865-576-5728

E-mail reports@osti.gov

Website http://www.osti.gov/contact.html

This report was prepared as an account of work sponsored by an agency of the United States Government. Neither the United States Government nor any agency thereof, nor any of their employees, makes any warranty, express or implied, or assumes any legal liability or responsibility for the accuracy, completeness, or usefulness of any information, apparatus, product, or process disclosed, or represents that its use would not infringe privately owned rights. Reference herein to any specific commercial product, process, or service by trade name, trademark, manufacturer, or otherwise, does not necessarily constitute or imply its endorsement, recommendation, or favoring by the United States Government or any agency thereof. The views and opinions of authors expressed herein do not necessarily state or reflect those of the United States Government or any agency thereof. 
Facilities and Operations

\title{
GRASSLAND ECOSYSTEM MANAGEMENT PLAN FOR THE OAK RIDGE RESERVATION
}

\author{
Jamie Herold \\ Facilities and Operations Directorate \\ Kitty McCracken \\ Environmental Sciences Division
}

Date Published: September 2018

Prepared by

OAK RIDGE NATIONAL LABORATORY

Oak Ridge, TN 37831-6283

managed by

UT-BATTELLE, LLC

for the

US DEPARTMENT OF ENERGY

under contract DE-AC05-00OR22725 



\section{CONTENTS}

ACRONYMS . $\mathrm{V}$

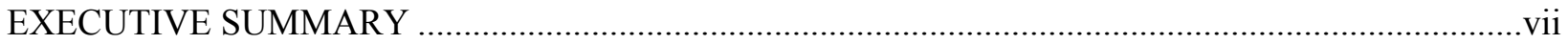

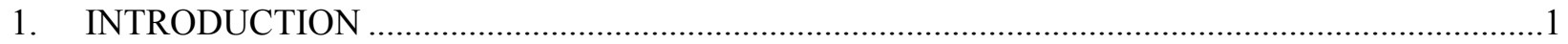

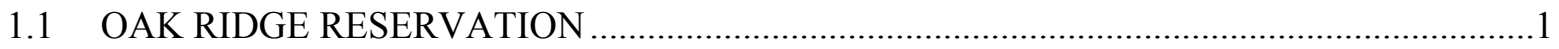

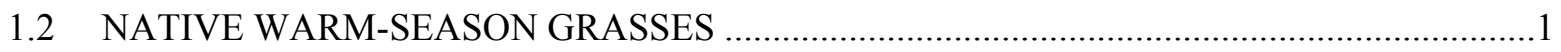

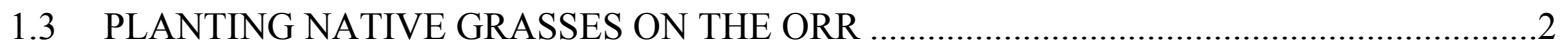

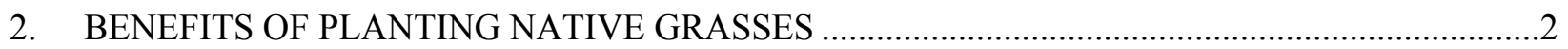

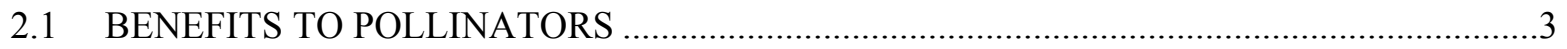

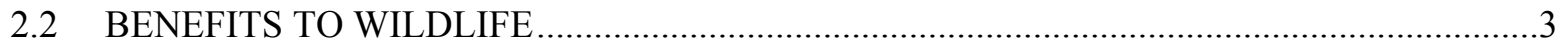

2.3 RESTORATION OF NATIVE PLANT AND WILDLIFE COMMUNITIES .........................4

2.4 ADDITIONAL BENEFICIAL CHARACTERISTICS OF NATIVE GRASSES ....................4

2.5 ECONOMIC BENEFITS OF PLANTING NATIVE GRASSES .......................................

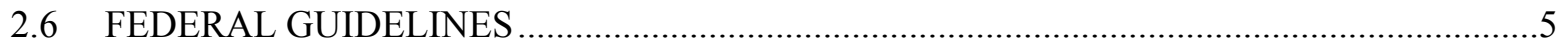

3. NATIVE GRASS SITE SELECTION STRATEGY FOR THE ORR …........................................

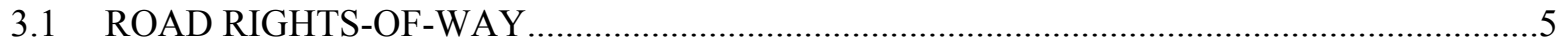

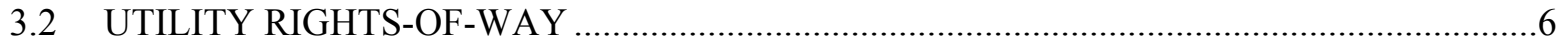

3.3 FALLOW HAY OR FORAGE FIELDS OF NONNATIVE GRASSES ...............................6

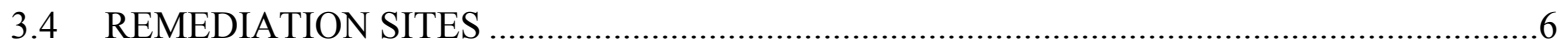

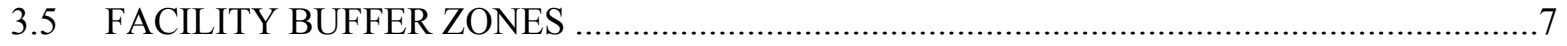

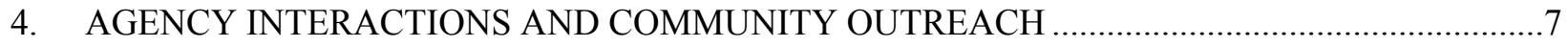

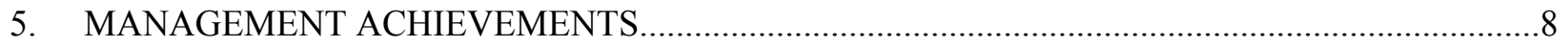

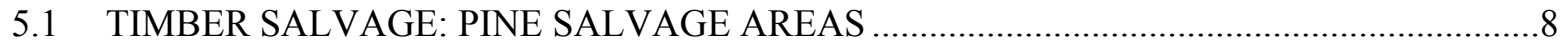

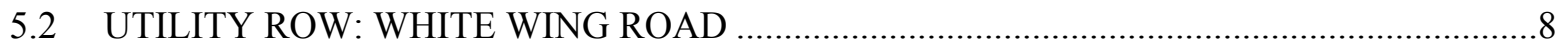

5.3 FACILITY BUFFER ZONES: HERITAGE CENTER, LLC/CROET .....................................

5.4 ABANDONED FESCUE FIELDS: BETHEL VALLEY BVR 2.4/2.6 .................................

5.5 WILDLIFE MANAGEMENT AREAS: THREE BENDS ...................................................

5.6 LAND USE CHANGE: BIOSOLIDS APPLICATION FIELDS ......................................

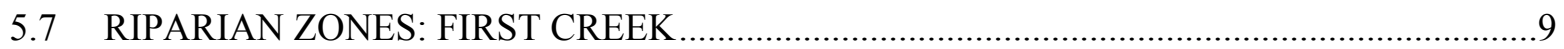

5.8 CULTURAL IMPROVEMENTS: WHEAT CHURCH VISTA …......................................

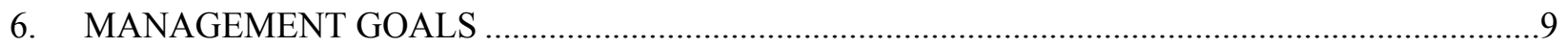

6.1 THREE BENDS WILDLIFE MANAGEMENT AREA …................................................

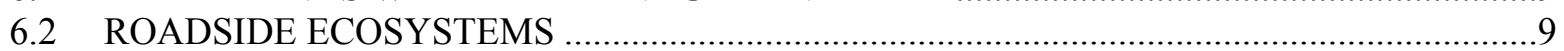

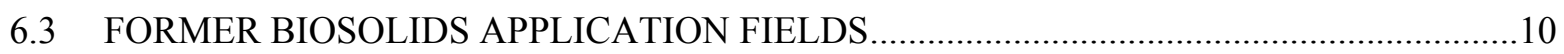

6.4 LANDSCAPING AND FACILITY BUFFER ZONES ................................................

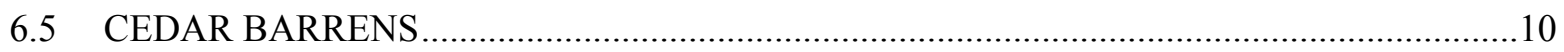

7. GUIDELINES FOR PLANTING AND MAINTAINING GRASSLANDS ON THE ORR ...............10

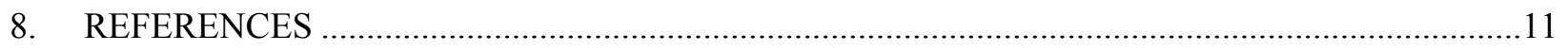

APPENDIX A. PLANTING GUIDE FOR NATIVE WARM-SEASON GRASSES ............................A-1

APPENDIX B. MAINTENANCE OF NATIVE WARM-SEASON GRASSLANDS ............................

APPENDIX C. COMMON WARM-SEASON NATIVE GRASSES ...................................................

APPENDIX D. EXAMPLES OF GRASSLANDS ON THE ORR .................................................. 



\section{ACRONYMS}

BORCE Black Oak Ridge Conservation Easement

CROET Community Reuse Organization of East Tennessee

DOE

EPA

ESD

Department of Energy

F\&O

FY fiscal year

Environmental Protection Agency

Environmental Sciences Division

GSMNP Great Smoky Mountains National Park

ORNL

ORR

PLS

Oak Ridge National Laboratory

TDEC

TDF

Oak Ridge Reservation

pure live seed

TWRA

Tennessee Department of Environment and Conservation

Tennessee Division of Forestry

Tennessee Wildlife Resources Agency 



\section{EXECUTIVE SUMMARY}

Land managers at the Department of Energy's (DOE's) Oak Ridge National Laboratory (ORNL) in East Tennessee are restoring native warm-season grasses and wildflowers to various sites across the Oak Ridge Reservation (ORR). Some of the numerous benefits to planting native grasses and forbs include improved habitat quality for wildlife, improved aesthetic values, and lower long-term maintenance costs. Native grassland restorations also help meet the goals of two recent presidential memorandums: "Incorporating Ecosystem Services into Federal Decision Making" and "Creating a Federal Strategy to Promote the Health of Honey Bees and Other Pollinators." 



\section{INTRODUCTION}

The Oak Ridge Reservation (ORR) is currently managed to promote a diversity of native plant communities, protect the value of the land and its resources, provide a buffer for the federal facilities located within its borders, and provide a research site for environmental issues. As part of this management strategy, the value of native plants is highlighted, including plant species in grassland communities. This document outlines the management strategy and role of grassland communities as part of the overall management approach for the ORR.

\subsection{OAK RIDGE RESERVATION}

The Department of Energy (DOE) ORR lies in the Valley and Ridge Physiographic Province, located between the Cumberland Plateau and the Smoky Mountains. It consists of 32,456 acres (13,134 ha) in Anderson and Roane Counties in East Tennessee. The land was originally purchased in 1942 by the federal government for the Manhattan Project. Three parcels of land were developed for that purpose, and the remaining forest was left intact for security purposes.

The Oak Ridge National Environmental Research Park, established by DOE in 1989, currently provides about 20,000 acres (8,094 ha) for research and education. The park was designated as an International Biosphere Reserve in 1989 and is also a unit member of the Southern Appalachian Biosphere Reserve. Currently, much of the ORR is a state wildlife management area, and wildlife management is coordinated through TWRA and the ORNL Natural Resources Management Team. (TWRA) (DOE 2007). In 1999, DOE designated 2,920 acres (1,182 ha) of the ORR as the Three Bend Scenic and Wildlife Management Refuge Area, which is managed by TWRA through an agreement with DOE. Additionally, three thousand acres $(1,214 \mathrm{ha})$ were protected through a conservation easement between DOE and the state of Tennessee in 2005. This easement, the Black Oak Ridge Conservation Easement (BORCE), is on the northern edge of the ORR along Poplar Creek and is managed by the TWRA and the Tennessee Department of Environment and Conservation.

\subsection{NATIVE WARM-SEASON GRASSES}

The native grasses typically used in planting and restoration efforts are native warm-season grasses, otherwise known as prairie or bunch grasses. These grasses grow in deep-rooted clumps and can grow up to $8 \mathrm{ft}(2.4 \mathrm{~m})$ tall. Native warm-season grasses bloom from June through September and complete their growth cycle in late summer or fall. In contrast, cool-season grasses, such as tall fescue, generally bloom in early spring, go dormant and do not grow vigorously during the summer, and then revive as temperatures cool in the fall. Many cool-season grass species are native to Europe and Asia and are adapted to the climates of those locations (Shea 1999).

Approximately 50 genera of native grasses are found in East Tennessee (Shea 1999). Warm-season grasses commonly used in planting and restoration efforts include big bluestem (Andropogon gerardii), Indian grass (Sorghastrum nutans), switch grass (Panicum virgatum), eastern gamma grass (Tripsacum dactyloides), little bluestem (Schizachyrium scoparium), and sideoats grama (Bouteloua curtipendula). A few examples are shown in Appendix C. The first four species in this list are tall grasses, which range from approximately 3 to $8 \mathrm{ft}$ ( 1 to $2.4 \mathrm{~m}$ ) in height and are typical components of the tall or mixed grass prairies. Little bluestem and sideoats grama grow from 2 to $4 \mathrm{ft}(0.6$ to $1.2 \mathrm{~m})$ tall and occur in the short and mixed grass prairies (Brown 1979).

Although most people think of prairies as occurring only in the midwestern United States, small grasslands and oak and pine savannas were an integral part of much of Tennessee when European settlers arrived (Packard and Mutel 1997). Today, only a few stands of remnant native grasses are found on the 
ORR. Most of these stands are found on remnant barrens ecosystems. After the end of the last ice age approximately 10,000 years ago, prairies began to extend into Tennessee (Shea 1999). The type of prairie found in East Tennessee barrens is characterized by the presence of native grass and forb (nonwoody herbaceous plants, such as wildflowers and legumes) species interspersed with a few cedar trees. Cedar barrens naturally occur on shallow, flaggy limestone soils and were once found throughout the Valley and Ridge Province. The shallow, dry soils prevent most tree species from becoming established (Mann et al. 1996).

A few small cedar barrens persist on the ORR. Raccoon Creek Barren is a representative cedar barren located near the western border of the reservation. Two others (including one that is home to one of the world's largest population of the Tennessee-listed tall larkspur, Delphinium exaltatum) are adjacent to Bethel Valley Road (Mann and Parr 1995). Many of the cedar barrens that once existed in the Valley and Ridge Province have been lost or degraded as a result of suppression of natural disturbances, dumping of debris, development, or exotic-species invasion (Mann et al. 1996).

The loss of grasslands in Tennessee mirrors a national trend. Today, less than $1 \%$ of the historic acreage of grassland ecosystems remains (Frost 2000; Kurtz 2001), and the populations of many animal species associated with grasslands (particularly grassland bird species) have declined (Madden et al. 2000; Brennan and Kuvlesky 2005). The large-scale disappearance of grassland ecosystems has sparked nationwide interest in restoring native grasses. Restoring native communities and improving the status of grassland wildlife are often the motivations behind replanting efforts. Prairie restoration has been carried out in parts of the Midwest for many decades (Kurtz 2001). Another DOE National Environmental Research Park, Fermilab, outside Chicago, is home to a model, restored prairie more than 1,200 acres (486 ha) in size. Land managers have been planting native grasses and wildflowers there for more than 25 years (Lane and BassiriRad 2005).

\subsection{PLANTING NATIVE GRASSES ON THE ORR}

The initial phases of the program to manage native grasslands on the ORR focused on learning about the planting and maintenance processes and conducting limited plantings. Efforts have included researching grassland restoration options, acquiring resources, and developing programmatic goals. Much of the progress occurred as a result of interacting with other agencies (e.g., the TWRA) and combining efforts with the nonnative invasive plant management program (McCracken and Giffen, 2017).

The original goals of the program were to create an atmosphere in which native grasslands could be managed, develop the support staff needed for successful implementation of the goals, initiate demonstration plantings under a variety of conditions, and support other groups when opportunities arose to conduct grassland restorations.

DOE natural resource managers and cooperating agencies and organizations are committed to pursuing the planting of native grasses on various parts of the ORR. In almost every case, these restoration efforts will be designed to create grassland communities that include a mix of native warm-season grasses and appropriate native wildflowers and forbs. This document is intended to guide the implementation of a native grassland community planting and restoration program for the ORR. Appendix D provides examples of existing grasslands found on the ORR.

\section{BENEFITS OF PLANTING NATIVE GRASSES}

The initiative to plant native grasses and forbs has been propelled by the recognition of the benefits-both economic and environmental - that native species provide. This section highlights the main benefits to the ORR of planting native grass and wildflower species. The following discussion does not include the 
benefits that native grasses provide to farmers, such as increased forage and soil conservation. This guide is intended, as much as possible, to be a practical document to support the restoration of native grassland communities on the ORR.

\subsection{BENEFITS TO POLLINATORS}

The 2014 presidential memorandum "Creating a Federal Strategy to Promote the Health of Honey Bees and Other Pollinators," was issued with the goals of reducing honey bee colony losses, increasing the monarch butterfly population, and increasing habitat acreage for all pollinators on federal land. Native grasslands that contain a high diversity of native forbs and grasses provide high-quality pollinator habitat.

Pollinators (including bees, butterflies, wasps, beetles, flies, moths, ants, and hummingbirds) depend on a diet of nectar and pollen. Some species are generalist pollinators and can feed from a variety of plant species; however, many others are specialists and require specific plants. Differences in pollen/nectar nutrition, flower shape, flower color, bloom time, and other plant characteristics attract different pollinators. The showpiece for this relationship is the monarch caterpillar, which will only feed on native milkweed species that are often found in grassland communities. Pollinators need a continuous source of food throughout their life cycle. The diverse mix of forbs associated with grassland ecosystems assures food sources throughout the growing season. To provide quality nectar and pollen sources, it is important that a diverse selection of native forb species bloom throughout the growing season.

Grassland ecosystems also provide nesting and shelter for a variety of pollinators. For instance, some bee and wasp species create nests by burrowing into the soil, and bunch grasses and forbs provide patches of bare ground where they can burrow. Other pollinators require different vegetation structures for nesting, such as hollow stems, tussocks, or flaky bark.

\subsection{BENEFITS TO WILDLIFE}

The clumped structure of native grass communities makes them an ideal habitat for wildlife that depend on grasses for cover, nesting, and food (Byre 1997). The tall upright structure of native grasses provides cover for small mammals, giving them some protection from avian predators. Native grasses stand upright under snow and continue to provide cover through the winter. The bare ground between grass clumps allows animals to move easily through the habitat and provides nesting space for grassland songbirds such as grasshopper sparrow (Ammodramus savannarum), bobolinks (Dolichonyx oryzivorus), and savannah sparrow (Passerculus sandwichensis). All of these songbirds have declining populations, resulting from the disappearance of their grassland habitats (Madden et al. 2000). Northern bobwhite quail (Colinus virginianus) populations have steadily declined in southeastern states, including Tennessee, over the past 30 years (Sibley 2001). Native grass plots are considered high-quality habitats and are preferred by nesting quail. Further, native grasses are usually found in diverse mixes and may coexist with a number of forb species. Grass and forb diversity translates into food diversity; a large variety of seeds and insect species attract a diverse combination of wildlife species. These animals include northern bobwhite, whitetailed deer (Odocoileus virginianus), eastern cottontail (Sylvilagus floridanus), eastern wild turkey (Meleagris gallopovo), various migratory songbirds, and small mammals such as voles and mice. The presence of rabbits and other small mammals will attract larger predator species, such as fox and raptors (Kline 1997a). In addition, a wide variety of butterflies and insects are attracted to the wildflowers and leaves found in native grassland communities (Taron 1997; Shea 1999).

In contrast to native grasslands, fescue fields have limited wildlife benefits. The dense, matted structure of tall fescue stands fail to provide cover, and the lack of bare ground prevents the easy movement, foraging, and nesting of animals in a field (Barnes et al. 1995). Tall fescue and other nonnative grasses often spread quickly, forming monocultures wherever they are planted. Tall fescue is often considered a nonnative 
invasive species (Miller 2003). Another drawback to planting tall fescue is an endophytic (i.e., living within the tissues of the grass) fungus (Neotyphodium coenophialum) that infects $97 \%$ of all tall fescue fields. (Native grasses are not susceptible to the fungus.) This fungus, although beneficial to the grass (infected fescue plants are more vigorous, more drought-resistant, and better tolerate poor soils), is toxic to herbivores (Bacon and Siegel 1988). Infected fescue is detrimental to wildlife because the endophyte produces alkaloids that are toxic to many species, such as deer, voles, mice, and others (Wolfe et al. 1998, Durham and Tannenbaum 1998). Tall fescue seeds are also known to have potentially harmful effects on northern bobwhite, some songbirds, and Canada geese (Branta canadensis) (Madej and Clay 1991). Many bird species have been shown to eat fescue seeds only as a last resort when other foods are offered (Conover and Messmer 1996). Some species might alter feeding habits in the wild to avoid fescue (Clay and Holah 1999).

\subsection{RESTORATION OF NATIVE PLANT AND WILDLIFE COMMUNITIES}

Restoration ecology is an outgrowth of the field of conservation biology, which is itself a relatively new field dedicated to conserving the world's biodiversity (Jordan 1997). Practitioners of restoration ecology aim to restore overexploited and/or degraded ecosystems and expand knowledge of ecosystem structure and function. Restoring native habitats has become increasingly popular as environmentalists and conservationists work to stem the tide of habitat destruction (Packard and Mutel 1997; Kurtz 2001). On the ORR, relatively large tracts of native forest ecosystems persist or are naturally recovering following previous human disturbance. Most human-impacted areas are dominated by nonnative species. Areas seeded with tall fescue and planted in pine plantation monocultures are common and do not represent valuable wildlife habitat. Restoring native grasses on the ORR will help expand native plant communities, and by association, native wildlife communities, and enhance a sense of this ecosystem's uniqueness.

\subsection{ADDITIONAL BENEFICIAL CHARACTERISTICS OF NATIVE GRASSES}

In addition to their benefits to wildlife, native warm-season grasses have a number of physical characteristics that make them attractive to land managers. Most native grass species spend their first growing season developing a strong root system, which will eventually extend to between 5 and $15 \mathrm{ft}$ (1.5 and $4.5 \mathrm{~m}$ ) into the soil (Shirley 1994). Although this characteristic results in a slower payoff above ground, the deep root system of native grasses is beneficial for the following reasons:

- By allowing the grasses to reach moisture, nutrients, and minerals far below the topsoil, the deep roots allow native grasses to flourish on marginal and droughty soils (Miller 1997).

- Deep roots help stabilize the soil and reduce erosion (Shea 1999).

- The large root mass of native grasses also increases soil fertility. The native grasses store carbon-rich compounds in the roots, and these are then exuded to the surrounding soils to serve as fodder for microbes (Miller 1997).

\subsection{ECONOMIC BENEFITS OF PLANTING NATIVE GRASSES}

Because native grasses are adapted to survive in a wide range of soil conditions, they usually require no fertilizer or irrigation after planting (Kurtz 2001). While it is true that there is significant short-term maintenance cost associated with stand establishment (Kline 1997a), after the second growing season, maintenance is usually a matter of a prescribed burn every $3-5$ years or at most one annual mowing. Over the long term, planting native grasses and wildflowers could reduce maintenance costs for land managers (EPA 1997). 


\subsection{FEDERAL GUIDELINES}

All of the benefits listed above are considered ecosystem services. On October 7, 2015, President Obama signed a presidential memorandum titled, "Incorporating Ecosystem Services into Federal Decision Making" (M-16-01). This presidential memorandum, "directs agencies to develop and institutionalize policies to promote consideration of ecosystem services, where appropriate and practicable, in planning, investments, and regulatory contexts."

\section{NATIVE GRASS SITE SELECTION STRATEGY FOR THE ORR}

The goal of restoring and maintaining native grass communities on the ORR is to provide grassland habitats, promote efficient management of grass areas, and reduce, when possible, costs associated with grass areas. Although many native grass restoration projects focus on establishing large tracts of open grasslands, the goals for the ORR are shaped more by the nature of East Tennessee habitats and the constraints associated with the presence of federal facilities. These requirements necessitate grasslands that are small in size and often placed adjacent to manmade structures or as buffers for other natural features. Some larger-scale grasslands have been established in the Three Bend area and are managed by TWRA. For the remainder of the ORR, the five main types of sites for conversion to grasslands include: (1) road rights-of-way, (2) utility rights-of-way, (3) fallow hay or forage fields of nonnative grasses, (4) select remediation sites, and (5) facility buffer zones. Other sites that could potentially be converted to grasslands include pine plantation areas damaged by southern pine beetles, spoils areas associated with construction activity, and areas treated for invasive plants. The primary sites suitable for grasslands are generally selected because they are currently managed as turfgrass areas, and conversion to native grass communities would be acceptable under current use requirements. By converting to native warm-season grasses, maintenance costs should decline, the wildlife should benefit, and the overall plant diversity of the ORR will be enhanced. In addition to these native grass conversion areas, the ORR will also include existing grasslands, primarily preserved cedar barrens. These goals of native grass restorations are consistent with generally available guidance on prairie restorations (Kline 1997b; Packard 1997).

\subsection{ROAD RIGHTS-OF-WAY}

Although the ORR is largely an isolated area with large tracts of undisturbed land, there are many facilities located throughout the reservation linked by an intricate network of roads. A few of the roads belong to the state of Tennessee and are maintained according to their guidelines. These are primarily larger roads, such as State Highways 58 and 95. Because they are under Tennessee Department of Transportation jurisdiction, they are not currently being considered for native grass conversion sites. However, there are more than 260 miles $(418 \mathrm{~km})$ of roads and associated rights-of-way within the ORR that are potential conversion sites (Parr 1999). This figure includes 78 miles (126 km) of road with higher travel rates that are bordered by wide (20 to $100 \mathrm{ft}$ [6 to $30 \mathrm{~m}$ ] on each side) grass buffers. Currently, these roads are mowed frequently and are generally planted in a mix of nonnative cool-season grasses such as fescue, Johnson grass (Sorghum halepense), and orchard grass (Dactylis glomerata). Conversion of these buffer zones will proceed as opportunities arise, following a standard plan. Due to the need to maintain safety sight lines, a narrow (8- to $12-\mathrm{ft}$ [2.4- to 3.6-m]) strip of nonnative grasses will border each side of the road. These strips will be mowed following existing management guidelines. Beyond these strips, the grass will be converted to a native warm-season grass mix that provides a useful transition from the managed roadway to the forest systems that occur over most of the ORR. Maintenance will be by a regimen of annual mowing, intermittent herbicide applications, and prescribed burns, depending on size and location. Additionally, security areas, such as the guard portals along Bethel Valley Road and Bear Creek Road, require that sight lines be maintained. Native grassland plantings in these areas would consist of shorter plants, such as little bluestem (Schizachyrium scoparium). 


\subsection{UTILITY RIGHTS-OF-WAY}

The ORR is traversed by several major utility rights-of-way, primarily for gas pipelines and electricpower transmission. Also, these rights-of-way are extended to provide service to all on-site facilities. For rights-of-way managed by DOE contractors, the easement for these utilities is maintained as a mowed area, with frequency of mowing varying from several times per year to once every $3-5$ years. Thus, existing vegetation varies from mixes of cool- and warm-season grasses to thickets of bushes and small trees. Conversion of the rights-of-way to a warm-season native grass community is part of a larger strategy to reduce maintenance costs (e.g., replacing shrubs/trees with grasses) and/or provide improved wildlife habitat and biodiversity (e.g., replacing turfgrass with bunch grasses). The timing and location of utility rights-of-way conversions would depend in part on the needs of the managing group. The goal would be to support these managers in their maintenance programs and aid them in converting to native species as part of an effort to streamline operations. Because the width of these utility corridors can be as much as $328 \mathrm{ft}(100 \mathrm{~m})$, and the total linear extent exceeds 162 miles $(260 \mathrm{~km})$, conversion of these areas could potentially create significant grasslands, and unlike many potential grass areas on the ORR, they would be long and connected, although narrow, expanses of grasses. This configuration could be very beneficial to grassland bird species and larger grazers. It would also reduce the density and dispersal of nonnative invasive species (McCracken and Giffen, 2017). After conversion to native grasses, the utility rights-of-way would probably continue to be maintained by a single annual mowing (or less frequently), although selected use of herbicides and prescribed burns might be suitable in some cases. Many of the electrical power transmission lines are owned and managed by the Tennessee Valley Authority (TVA), and they will continue to be managed by that organization, though cooperative management with DOE contractors continues to be a possibility.

\subsection{FALLOW HAY OR FORAGE FIELDS OF NONNATIVE GRASSES}

Since acquisition of the ORR, a portion of the site has been maintained as pasture. These fields have historically been used as hay fields or occasionally as forage for domestic livestock. In 1996, it was estimated that almost 700 acres were managed as agricultural fields (Mann et al. 1996). Currently, the haying program has been eliminated, and livestock are no longer managed on the ORR. A majority of these hay fields are slowly transitioning into forested areas or are maintained by infrequent mowing. Conversion to native grass communities could be accomplished at these sites at low costs because of the minimal site preparation required. These sites could serve as locations for warm-season grasslands, especially if they border other potential conversion targets such as rights-of-way. The maintenance regime for the native grass areas in fallow fields would probably continue to consist of mowing and selected application of herbicides, but prescribed burns might be suitable where acreage is large or the field is easily isolated by firebreaks.

\subsection{REMEDIATION SITES}

The ORR is in a constant state of flux. Contaminated areas are fenced off and remediated, old buildings are rehabilitated or razed, and new buildings are constructed. Whenever new construction projects are started, large areas of vegetation are cleared. The bare ground left behind after construction is often seeded with nonnative grasses and is vulnerable to exotic pest plant invasions. These construction areas could be targeted for native grass plantings. The decision to use native grasses in these areas should be determined by the planned maintenance regime. If the site is to be allowed to return to shrubs and trees or cut only infrequently, then planting native grasses would be appropriate. Some circumstances might require use of annual nonnative cover species. If the area is to be mowed frequently (i.e., more than twice a year), then a turfgrass approach is recommended. 
As part of the environmental cleanup associated with the federal facilities on the ORR, many sites have been treated or cleaned to remove contaminants or residual wastes. Other areas have been converted to storage or isolated waste landfills to handle wastes and remediation products from other locations on the ORR. In addition, some sites have been enhanced to create improved or unique environments, such as wetlands. Bear Creek Valley currently has many of these waste storage locations, and the total acreage represented by such sites is considerable. Many of these sites are maintained as mowed areas and currently are planted with a fescue-based grass mix. These remediated sites could be potential locations for native grass conversions if the bunch grass root systems do not threaten the integrity of the landfill caps or if sufficient area is available adjacent to the caps. Other remediation sites would include areas previously used for application of biosolids. The maintenance regime for the converted native grass areas would likely continue to be mowing and selective application of herbicides, but prescribed burns might be suitable where acreage is large.

\subsection{FACILITY BUFFER ZONES}

Besides utility corridors, there are a number of other areas around the ORR that are currently landscaped with nonnative grasses. The 1995 Guidance for Presidential Memorandum on Environmentally and Economically Beneficial Landscape Practices on Federal Landscaped Grounds declared that native plants should be used in landscaping whenever possible (EPA 1995). Certainly, growing large stands of prairie grasses next to buildings is neither practical nor safe. There are, however, areas near buildings that are lightly traveled or that abut forestland or roads. The majority of these areas are currently landscaped with tall fescue and/or other nonnative grass species. These landscaped sites could be converted to a native grass/wildflower mix to create bird and butterfly habitat, as well as a more aesthetically pleasing landscape. A reduction in mowing costs would be a clear economic benefit of landscaping with native grasses and wildflowers.

\section{AGENCY INTERACTIONS AND COMMUNITY OUTREACH}

Working relationships with various organizations, agencies, and individuals has been invaluable to restoration of native grassland communities on the ORR. Some of the collaborations over the past decade include the Tennessee Wildlife Resource Agency, the Tennessee Department of Environment and Conservation, the Tennessee Department of Forestry, the Tennessee Valley Authority, NatureServe, and the Natural Resources Conservation Service. In addition, numerous interactions with universities, nurseries and various organizations have increased the knowledge and research base associated with grassland communities on the ORR. Such interactions have allowed multiple entities to achieve more success with the same individual effort.

One of the objectives of native grass restoration on the ORR is to bring attention to the ORR as a leader in environmental and energy research and involve local communities in the program. Demonstration plots near the three DOE facilities were selected for their visibility and ability to highlight this ecosystem to staff and visitors. These high visibility areas include multiple grassland restoration sites along Bethel Valley Road to Oak Ridge National Laboratory (ORNL), native grass fields in the vicinity of the Y-12 New Hope Visitor Center and Scarboro Road, and native grasslands adjacent to and within the East Tennessee Technology Park. In addition, outreach programs such as the ORR Nature Walks and Earth Day events have been held in various ecosystems on the ORR, including grassland habitats.

The following website was developed to document the planting process on the ORR: $\mathrm{http} / /$ www.esd.ornl.gov/facilities/nerp/nativegrasspics.html. The site has pictures of the plantings, a description of the planting process, and links to other native grass websites. The site is tailored for curious local citizens, as well as land managers around the country who are interested in native grass restoration. An informative brochure on native grass management on the ORR has been developed, which is also 
available through the website. ORNL researchers also contribute to onsite publications and local news media and make presentations to appropriate groups regarding the native grass restoration process.

Native grass plantings can also be used to form links with local garden clubs, environmental organizations, and schools. Native grass restoration presents land managers with an excellent vehicle for informing the community of the value of the ORR as a venue for environmental research.

In 2018, Southern Appalachian Man and the Biosphere's (SAMAB) and the Eastern Band of Cherokee Indians (EBCI), decided to form a working group for a Culturally Significant Plants Species Initiative (CSPSI). As one of the biosphere reserve units within SAMAB, the ORR will be actively participating in this initiative. One of the goals of the project is for land management agencies, including the ORR, to develop partnerships with EBCI to promote restoration, research and education of culturally significant plant species within the southern Appalachian forest region. Potential projects could include seed collection for an EBCI seed bank, species relocation and management, and research on management practices.

\section{MANAGEMENT ACHIEVEMENTS}

The following is a selected list of grassland restoration sites on the ORR. Many of these are projects from early stages of the grassland management program in the early 2000s. After a decade or more, these grasslands are still providing wildlife habitat, ecosystem services, and cost savings. Invasive plant control and land management continue on these areas. Many more acres have been converted to grasslands since the beginning of this program.

\subsection{TIMBER SALVAGE: PINE SALVAGE AREAS}

During the period from 1993 to 2001, the ORR experienced the worst outbreak of southern pine beetles in its recorded history (Roy, Evans, and Ryon 2001). As a result of this outbreak, the ORR has thousands of dead pine trees covering about 2,000 acres. Some of these acres were logged as a salvage effort, leaving bare areas. In 2002 and 2003, 14 acres along Bethel Valley Road were planted with native grasses and wildflowers.

\subsection{UTILITY ROW: WHITE WING ROAD}

Grassland plant species were planted in the widened portion of an existing powerline as part of a remediation effort in 2003. Forty acres of native warm-season grass and wildflower seeds were planted using a rotary broadcaster. Although a heavy cover crop of rye likely delayed grassland establishment, a field of native grasses and wildflowers was established by summer of 2005 .

\subsection{FACILITY BUFFER ZONES: HERITAGE CENTER, LLC/CROET}

Open lawn areas at the Heritage Center were converted to native grasses and wildflowers by the Community Reuse Organization of East Tennessee (CROET), TWRA, and ORNL Natural Resources personnel, creating a business park campus that is visually appealing and environmentally sound. The project began in 2006 and planting continued for multiple years. Fields were planted with either switchgrass monocultures or were planted with a diverse mix of forbs and grass.

\subsection{ABANDONED FESCUE FIELDS: BETHEL VALLEY BVR 2.4/2.6}

Over 40 acres of warm-season native grasses were planted in 2002 and 2003. Site preparation included bush-hogging and herbicide. A no-till drill was used to plant five different zones of native grass: little 
bluestem, big bluestem, Indian grass, switchgrass, and a wildlife mix. The wildlife mix consisted of three grasses and four wildflowers. Invasive plant species remained a problem, but a good stand of native grass and wildflowers developed.

\subsection{WILDLIFE MANAGEMENT AREAS: THREE BENDS}

The mowed fescue/scrub fields at Freels Bend provided minimal habitat and food value for wildlife. Site preparation began in April 2002, including mowing, herbicide application, and prescribed burning. A notill drill was used for planting. Through the years, bush hogging, mowing, herbicide application and prescribed burning conducted by TWRA, ORNL Natural Resources personnel and the Tennessee Division of Forestry have been utilized to keep many fields as grassland habitat for wildlife.

\subsection{LAND USE CHANGE: BIOSOLIDS APPLICATION FIELDS}

Fallow fescue fields, formerly used for biosolids application, were targeted for conversion to native warm-season grasses. Conversion of small acreages of these fields began in FY 2007. Sites were sprayed to remove nonnative species, and a tall-grass community was planted. The work was the result of a combination of input from the Biosludge Steering Committee and effort from ORNL Environmental Sciences Division (ESD), East Tennessee Mechanical Contractors, DOE, and the city of Oak Ridge.

\subsection{RIPARIAN ZONES: FIRST CREEK}

The First Creek riparian restoration area consists of approximately 2 acres at the southwest corner of Bethel Valley Road and First Street. In 2003, a mowed turf grass area was converted to native grassland using a no-till drill and planting plugs of native species. The area is only about 2 acres in size, but it borders a wetland remediation site and small portion of forested area on the ORNL campus.

\subsection{CULTURAL IMPROVEMENTS: WHEAT CHURCH VISTA}

An open vista of the church was desired by the Wheat Community ancestors. The vista had previously been cleared in 1995, but lack of attention led to mixed shrub and tree growth impairing the view. Clearing and site preparations began in 2007, and three acres of switch grass and mixed grass stands were planted in the following years. The vista has been maintained through prescribed burns.

\subsection{EU-29 POLLINATOR FIELD}

The EU-29 pollinator field is a four-acre parcel of land planted with a mix of native grass and forbs in March 2017. This area was the former location of building K-1407-C, just north of the Central Neutralization Facility at ETTP. After the area was excavated, new topsoil was added to the site and a native seed mix was planted with a no-till drill. At the request of ETTP, the Natural Resources Management Team helped develop the planting plan to restore the area to pollinator and wildlife habitat.

\section{MANAGEMENT GOALS}

The planned program goals for the next 5 years are based on the funding level as well as the opportunities available to convert areas to native grasslands. The projected program includes six primary goals, as described in the following sections. 


\subsection{THREE BENDS WILDLIFE MANAGEMENT AREA}

Many fields on the Three Bends will continue to be managed as early succession habitat through mowing, disking, herbicide application, and prescribed burning. In the past, sixty acres on Freels Bend had been kept as fescue and Johnson grass pasture for geese. Approximately half of this area is being converted to native forb and grass species, and the other half will become wildlife food plots. In addition, approximately 100 acres of young forest is being converted into prairie ecosystem to provide wildlife habitat. Plans are being developed to increase the acreage of savanna and woodland ecosystems as well, which will have a diverse species of early successional native grass and forb species.

\subsection{ROADSIDE ECOSYSTEMS}

Management plans for the most cost-efficient, ecosystem beneficial, and aesthetically pleasing roadsides are being evaluated. In FY 2014, the Roadside Ecosystem Improvement Assessment was prepared to evaluate the mowed roadside along Bear Creek Road, Bethel Valley Road, Bull Bluff Road, and Perimeter Road on the ORR. These areas consist of as much as 90 acres of mowed area. The proposed alternative to the current mowing regime offers an opportunity to maintain the roadsides at the current level of safety and visibility while enhancing the roadside ecosystem and potentially reducing maintenance costs through reduced mowing volume and frequency. It also offers a path toward a selfsustaining roadside ecosystem.

Further evaluation into ways to limit deer-vehicle collisions by changing the species found on the roadside is also being conducted. Many nonnative grasses used for roadside turf are cool-season species. These species do most of their growth during the coolest times of the growing season in early spring and late fall, going dormant in the heat of the summer. Therefore, these grasses are actively growing and provide palatable forage during times when other food sources are scarce. This could inadvertently draw deer closer to the roadsides where deer-vehicle collision can occur. The goal will be to plant less palatable plant species and avoid plants that are green during times of the year when other food is scarce.

\subsection{FORMER BIOSOLIDS APPLICATION FIELDS}

Two former biosolids application sites are being targeted for conversion into grassland habitat. The first is approximately 300 acres located at the intersection of Scarboro and Bethel Valley Roads. Some of these fields were previously planted with native grasses and wildflowers, but over time parts of these fields were invaded by autumn olive and other invasive plant species. Other areas are forested and will be thinned to create more open woodland and savanna habitat. Still other sections are currently mowed fescue fields. These fescue fields will be sprayed with herbicide to kill the fescue, thus allowing the native seedbank to regenerate. The second former biosolids application site, located on Watson Road, is now a University of Tennessee study site for research on converting fescue fields to grasslands. The research focuses on the plant communities that naturally emerge after herbicide application to remove fescue. These ecosystem restorations and research projects are aimed at helping to reduce maintenance costs, reduce deer-vehicle collisions, improve wildlife habitat, and increase pollinator habitat.

\subsection{LANDSCAPING AND FACILITY BUFFER ZONES}

Incorporation of grassland communities in landscaping and facility buffer zones continues to be a management goal. Multiple areas surrounding the three Oak Ridge DOE facilities have been converted to grasslands, integrating facilities into the surrounding ecosystem. Converting mowed turf areas to native grasses and forbs supports wildlife, is aesthetically appealing, and reduces overall maintenance needs. These transitions provide wildlife and pollinator habitat. Many riparian zones, roadsides, utility rights-of- 
way, and fescue fields have already been converted; however, there are numerous possibilities to introduce more grassland communities.

\subsection{CEDAR BARRENS}

Multiple cedar barrens occur on the ORR. Cedar barrens have shallow rocky soils with bedrock outcroppings and are dominated by perennial grasses and forbs. Because they are not disturbed by fire, some of these barrens have become overgrown with both native and invasive brush. Plans are being developed to manage these habitats through selective thinning.

\section{GUIDELINES FOR PLANTING AND MAINTAINING GRASSLANDS ON THE ORR}

There are no clear guidelines to planting and managing native grasses and forbs. General guidelines for planting (Appendix A) and maintenance (Appendix B) have been compiled for the ORR, but each site will require a customized approach. The key will be to remain flexible in the approach and build on what has been demonstrated to be successful on the ORR. A number of important factors must be considered when planning a native grass restoration project, including date and season of planting, site selection, site preparation, planting methods, seed mixtures, maintenance, monitoring, and costs. Depending on the source, one or more of these is considered most important to ensuring success with native grass plantings. Short discussions of these factors are provided in Appendices A and B. The selection of sites is based on an overall management strategy for the ORR outlined in Section 3.

The following list includes lessons learned from successful conversions:

- Pine areas can be successfully converted, but site preparation is extensive and expensive, usually requiring a bog harrow and burning or piling of debris using a bulldozer. Soils are of high quality, and communities can be established in a year. Drilling works best, but broadcast seed can be successful if followed by sufficient rain and if weed competition is minimal.

- Fallow fields can be successfully converted within a couple of years. Drilling works well, but soil preparation (e.g., disking) increases success, and weed control is critical and often difficult.

- Utility and road rights-of-way can be successfully converted in as little as a year, but only if soil is of high quality or is supplemented during planting with fertilizer and/or lime.

- Grass plugs are useful in limited situations, but post-planting conditions, especially sufficient rain, must be optimal for highest success.

- Although grass and wildflowers can be planted at the same time, if weeds are an issue, it might be more efficient to plant only grasses at first, and then, after a couple years of herbicide control, to add wildflowers.

- Conversion to grasslands can invite unwanted pests; in particular, the spread of fire ants can be increased by disturbances. Other immigrants, such as volunteer wildflowers, might be more desirable.

- Success rates should not be judged on first-year observations alone. Successful conversion could take longer, especially if soils are poorer, but invasive plants must be monitored or controlled more extensively if grassland establishment is slower. 


\section{REFERENCES}

Bacon, C. W., and M. R. Siegel. 1988. "Endophyte Parasitism of Tall Fescue.” Journal of Production Agriculture 1: 45-55.

Barnes, T. G., L. A. Madison, J. D. Sole, and M. J. Lacki. 1995. "As Assessment of Habitat Quality for Northern Bobwhite in Tall Fescue Dominated Fields." Wildlife Society Bulletin 23: 231-237.

Brennan, L. A., and W. P. Kuvlesky. 2005. "North American Grassland Birds: An Unfolding Conservation Crisis?" Journal of Wildlife Management 69: 1-13.

Brown, L. 1979. Grasses: An Identification Guide. New York: Houghton Mifflin.

Byre, V. J. 1997. “Birds.” In The Tallgrass Restoration Handbook: For Prairies, Savannas, and Woodlands, 327-338. Washington, DC: Island Press.

Clay, K., and J. Holah. 1999. "Fungal Endophyte Symbiosis and Plant Diversity in Successional Fields." Science 285: 1742-1744.

Conover, M. R., and T. A. Messmer. 1996. "Consequences for Captive Zebra Finches in Consuming Tall Fescue Seeds Infected with Endophytic Fungus Acemonium conoephialum.” The Auk 113: 492-495.

Department of Energy (DOE). 2007. Oak Ridge Reservation Ten Year Site Plan. Oak Ridge, TN: Oak Ridge Office US Department of Energy; DOE/ORO-TYSP2007.

Durham, W. F. and M. G, Tannenbaum. 1998. Effects of Endophyte Consumption on Food Intake, Growth, and Reproduction in Prairie Voles." Canadian Journal of Zoology 76 (5):960-969.

Environmental Protection Agency (EPA). 1995. Guidance for Presidential Memorandum on Environmentally and Economically Beneficial Landscape Practices on Federal Landscaped Grounds. FRL-5275-6. Federal Register 60(154): 40837-40841, August 10.

http://www.epa.gov/docs/fedrgstr/EPA-GENERAL/1995/August/Day-10/pr-664.html.

1997. A Source Book on Natural Landscaping for Public Officials. Environmental Protection Agency, Washington, DC. http://www.epa.gov/glnpo/greenacres/toolkit/index.html.

Frost, C. 2000. "Native Grasses and Grasslands in the Presettlement Landscape of Eastern North America." In Proceedings of the Second Eastern Native Grass Symposium: Baltimore, Maryland, November 17-19, 1999, 10.

Jordan, W. R. 1997. "Foreword.” In The Tallgrass Restoration Handbook: For Prairies, Savannas, and Woodlands, xiii-xviii. Washington, DC: Island Press.

Kline, V. M. 1997a. "Planning a Restoration.” In The Tallgrass Restoration Handbook: For Prairies, Savannas, and Woodlands, 31-46. Washington, DC: Island Press.

—. 1997b. "Orchards of Oak and Seas of Grass." In The Tallgrass Restoration Handbook: For Prairies, Savannas, and Woodlands, 3-22. Washington, DC: Island Press.

Kurtz, C. 2001. A Practical Guide to Prairie Reconstruction. Iowa City: University of Iowa Press. 
Lane, D. R., and H. BassiriRad. 2005. "Diminishing Spatial Heterogeneity in Soil Organic Matter across a Prairie Restoration Chronosequence.” Restoration Ecology 13: 403-412.

Madden, E. M., R. K. Murphy, A. J. Hansen, and L. Murray. 2000. "Models for Guiding Management of Prairie Bird Habitat in Northwestern North Dakota." American Midland Naturalist 144: 377-392.

Madej, C. W. and K. Clay. 1991. "Avian Seed Preference and Weight Loss Experiments: the Effect of Fungal Endophyte-infected Tall Fescue Seeds. Oecologia 88:296-302.

Mann, L. K., and P. D. Parr. 1995. "Oak Ridge Reservation: Nationally Valuable Resource.” Oak Ridge National Laboratory Review 28(1). http://www.ornl.gov/ORNLReview/rev28-1/text/orr.html.

Mann, L. K., P. D. Parr, L. R. Pounds, and R. L. Graham. 1996. "Protection of Biota on Nonpark Public Lands: Examples from the U.S. Department of Energy Oak Ridge Reservation." Environmental Management 20(2): 207-218.

McCracken, M. K. and N. R. Giffen. 2017. Invasive Plant Management Plan for the Oak Ridge Reservation. Oak Ridge, TN: Oak Ridge National Laboratory: ORNL/TM-2004/98/R2.

Miller, J. H. 2003. "Nonnative Invasive Plants of Southern Forests: A Field Guide for Identification and Control." US Department of Agriculture, Forest Service, Southern Research Station, Asheville, NC; SRS-62.

Miller, R. M. 1997. "Prairie Underground." In The Tallgrass Restoration Handbook: For Prairies, Savannas, and Woodlands, 23-30. Washington, DC: Island Press.

Mitchell, J. M., E. R. Vail, J. W. Webb, A. L. King, and P. A. Hamlett. 1996. "Survey of Protected Terrestrial Vertebrates on the Oak Ridge Reservation." Oak Ridge, TN: Oak Ridge National Laboratory; ES/ER/TM-188.

Packard, S. 1997. "Restoration Options." In The Tallgrass Restoration Handbook: For Prairies, Savannas, and Woodlands, 47-62. Washington, DC: Island Press.

Packard, S., and C. F. Mutel. 1997. "Perspective." In The Tallgrass Restoration Handbook: For Prairies, Savannas, and Woodlands, xix-xxviii. Washington, DC: Island Press.

Parr, P. D. 1999. Oak Ridge Reservation Management Plan. Oak Ridge, TN: Oak Ridge National Laboratory; ORNL/M-6614.

Roy, W. K., J. W. Evans, and M. G. Ryon. 2001. “The Red-Headed Woodpecker and Brown-Headed Nuthatch on the Oak Ridge Reservation: Relationship to Recent Landscape Changes." The Migrant 72: $1-12$.

Shea, A. 1999. "The Return of Native Grasses to Tennessee.” The Tennessee Conservationist, September/October 1999. http://www.state.tn.us/environment/tn_consv/archive/grass.htm.

Shirley, S. 1994. Restoring the Tallgrass Prairie. Iowa City: University of Iowa Press.

Sibley, D. A. 2001. The Sibley Guide to Bird Life and Behavior. National Audubon Society. New York: Alfred A. Knopf. 
Taron, D. J. 1997. "Insects.” In The Tallgrass Restoration Handbook: For Prairies, Savannas, and Woodlands, 305-318. Washington, DC: Island Press.Wolfe, B. A., M. Bush, S. L. Monfort, A. Pessier, and R. J. Montali. 1998. "Abdominal Lipomatosis Attributed to Tall Fescue Toxicosis in Deer." J. Am. Vet. Med. Assoc. 15:213 (12): 1783-86. 



\section{APPENDIX A. PLANTING GUIDE FOR NATIVE WARM-SEASON GRASSES}





\section{APPENDIX A. PLANTING GUIDE FOR NATIVE WARM-SEASON GRASSES}

\section{A.1 WHEN TO PLANT}

The seasonal timing for planting native grass and wildflowers is not the most critical factor in the subsequent success of a stand. Stands have been successfully established through both spring and fall plantings. For fall plantings, ground temperature at the time of seeding is critical, whereas moisture is the key factor for spring plantings.

Spring plantings - Native grasses may be planted in the spring any time after the ground thaws until the middle of summer, when dry weather and high temperatures will desiccate and kill seeds. Native grasses have higher germination rates with spring plantings than with fall plantings. A late spring seeding, between May 15 and June 15, is preferred because it takes advantage of the frequent rains and warm temperatures that present optimal conditions for germination and growth. Planting earlier in the spring will require more effort in controlling competition, as cool-season grasses and weeds, which germinate earlier than native warm-season grasses, will have a head start and will out-compete the slower-growing native species (Diboll 1997).

Fall plantings - When native grasses are planted in the fall, the seeds will lay dormant in the soil over the winter before germinating the following spring. Thus, fall plantings are also called dormant-season plantings (Diboll 1997). There are two main advantages to dormant-season seeding:

1. Fall plantings follow the natural cycle of seed set and germination. Native grass seeds have evolved to germinate following a period of exposure to cold temperatures. The cool temperatures of winter will help break dormancy in the seed. With a spring planting, some seeds might not germinate until the following spring, particularly if they are not stratified (Kurtz 2001).

2. As a general rule, perennial wildflowers have higher germination rates when planted in the fall. Thus, seed mixes with a high proportion of wildflowers might benefit from a dormant-season planting (Diboll 1997).

There are also a number of cautionary notes and considerations that must be taken into account when contemplating a fall planting (Kurtz 2001; Diboll 1997; Morgan 1997):

- Seeds should not be planted until the ground temperature is below $55^{\circ} \mathrm{F}\left(13^{\circ} \mathrm{C}\right)$, but before the ground freezes. In Tennessee, this will generally allow planting between November 1 and mid-December. At higher temperatures, grass seeds might germinate and subsequently be killed when winter arrives. These possibilities make dormant-season plantings slightly risky. It is possible that by the time the ground temperature gets below $55^{\circ} \mathrm{F}\left(13^{\circ} \mathrm{C}\right)$, the weather will be too inclement to accommodate planting activities. If this situation should occur, seeding would have to be delayed till spring. If a dormant-season planting is deemed desirable, the crew must be ready to plant on a moment's notice to take advantage of the first ideal planting day.

- A cover crop may be planted along with the target species to protect the seeds in the soil, especially if slope or locations raise concerns about erosion control.

- It is advisable to increase fall planting rates by $25 \%$ over spring rates because seeds will be lost to erosion, wildlife, and rotting over the winter.

- Weed competition will be more intense than with a spring planting because cool-season weeds will have an opportunity to become established before the native grass seeds germinate. 
- Planting depth should not exceed $1 / 4$ in. $(0.6 \mathrm{~cm})$ because winter freezing and thawing will tend to push seeds down even farther, reducing the likelihood of satisfactory germination.

\section{A.2 SITE PREPARATION}

Some native grass experts contend that either seed quality or post-planting competition control is the most essential factor to ensure native grass planting success. Without an appropriately prepared seedbed, however, these considerations are rendered moot. To ensure the best chance of success with a native grass planting, a clean, firm seedbed is desirable. Firming up the seedbed until the soil is well-packed has a number of advantages: (1) it eliminates air passages that expedite soil, and therefore seedling, desiccation; (2) it forms a crust at the soil surface that reduces soil evaporation and desiccation; and (3) it ensures good seed-to-soil contact (Morgan 1997).

Proposed planting sites on the ORR will be in various states of readiness. Some sites could be covered with logging debris and stumps, and others might be covered with tall fescue and other plants. Depending on the preplanting status of the proposed site, any number of steps might need to be taken in advance of seeding. These steps could include clearing, disking, rolling, and/or applying herbicides. There is no standard set of actions that must be taken to prepare a seedbed because every site is different. This fact must be kept foremost in mind when planning to prepare a site for a native grass planting.

\section{A.2.1 CLEARING/MOWING}

The proposed pine-plantation restoration sites are littered with logging debris and leftover stumps from pine-logging operations. This material must be cleared before any serious seedbed preparation commences. In addition to simply dragging out much of the debris, two techniques can be used to deal with the stumps. First, they can be removed, which would probably require the use of a bulldozer. Alternatively, the stumps can be ground down to a level that would allow mowing and planting activities to commence. On many of the logged sites, there are too many stumps to make grinding a viable option. Another option is to use a bog harrow to cut up debris and stumps, but the harrow would also mix the debris into the surface soils. On most ORR sites, several passes with the harrow would be necessary to sufficiently grind the debris and stumps.

On power-line rights-of-way, it might be necessary to mow or use a rotary cutter (e.g., Bush $\operatorname{Hog} ®)$ to cut the existing vegetation, particularly woody plants. On sites with extant tall fescue or other grass and herbaceous populations, it will be necessary to clear all of the vegetation to reduce post-planting weed competition as much as possible. The amount of existing vegetation will determine the intensity of the preparatory effort. Any attempt to expeditiously clear a site of existing vegetation will probably require the use of herbicides (Morgan 1997; Kline 1997).

\section{A.2.2 HERBICIDE USE}

A large determinant in the success of a native grass planting is the degree to which the native plants have an opportunity to establish in the face of weedy competition. Although there are environmental concerns attached to the use of herbicides, they are an effective way to kill existing vegetation, reduce establishment competition, and create a clean seedbed.

A critical problem with herbicide applications is that one spraying is usually not enough to eliminate competition to any degree. Many weedy grass and herbaceous species will recover by sprouting from rhizomes (underground horizontal stems), or from seeds stored in the seed bank. In addition, various weeds will sprout at different times during the spring, and so an early-spring application might miss latesprouting species. Thus, multiple applications of herbicide are usually necessary to adequately kill 
existing vegetation (Morgan 1997; Kline 1997). Disking or raking the dead material following an herbicide application might be desirable to expose the soil and create a cleaner seedbed.

For preplanting applications, a glyphosate herbicide such as Roundup ${ }^{\circledR}$ is typically used. This type of herbicide translocates through the target plant after a foliar application, slowly (4-7 days) killing the entire plant. These herbicides are effective only when the target plant is actively growing. Glyphosate herbicides should not be used after planting because the herbicide is nonspecific and will kill native grasses and forbs as well as undesirable weed species (Kurtz 2001). Depending on the diversity of the extant vegetation, a mixture of herbicides, instead of just Roundup, might be needed. In particular, glyphosate by itself sometimes does a poor job of controlling broadleaf species. Adding a triclopyr herbicide to the tank mixture can help solve this problem (Morgan 1997). ORR land managers should consult with an individual experienced in native grass site preparation to identify the herbicide, or mix of herbicides, necessary to clear seedbeds.

Herbicides can be applied in any number of ways. Large sprayers attached to tractors are convenient for large areas and when the plants to be sprayed are uniformly spread throughout the area. Backpack sprayers can be used for spot treatment of individual plants or small areas. A third method, wick application, can also be used. It could be necessary to use multiple application methods on a single siteusing the large sprayer for the first and/or second applications to broadly kill the existing vegetation, and then following up before planting with the backpack sprayer to kill any lingering weeds. The spraying rate used to kill the existing vegetation will largely depend on the species present and the density of the vegetation. The user should refer to the herbicide labels for rate recommendations.

\section{A.2.3 NONCHEMICAL SEEDBED PREPARATION}

Because of the possible negative effects to the environment, some people are uncomfortable using large amounts of herbicides to kill the existing vegetation on a planting site. A clean seedbed can also be prepared without using herbicides through an intense schedule of plowing and disking in the months before planting. Compared with herbicide application, this method is likely to require more intense labor and time commitments and generally results in inferior control of persistent perennial weeds (Morgan 1997). Someone with experience in preparing a seedbed without using herbicides should supervise such operation.

\section{A.3 PLANTING METHODS}

A number of techniques and types of equipment can be used to plant native grasses and forbs. Each of the methods has benefits and drawbacks that must be weighed when considering which one to use. Based on published information, certain planting methods tend to be more successful and cost-effective than others. This published information must be considered alongside the equipment and knowledge already available at the ORR to determine the optimal planting method.

\section{A.3.1 DRILLING}

Native grass drills (e.g., no-till or rangeland drills) are the preferred pieces of equipment for planting native grasses (Morgan 1997). As previously stated, Indian grass, big bluestem, and little bluestem all have fluffy seeds that are not compatible with conventional grain drills. No-till native grass drills are designed to handle fluffy seeds (do not attempt to use a native grass drill to plant "debearded" native grass seeds), and they can be adjusted to plant at any desired depth. Switch grass seeds are small and hard and thus can be planted using either a no-till or conventional drill. The same is true of sideoats grama, which has traditional oat-shaped seeds. Eastern gamma grass is a relative of corn and must be planted using a 
corn planter. Seeds of multiple species can be thrown into the same drill hopper to create a random, heterogeneous native grass landscape.

No-till drills operate by opening up a small trench in the soil, dropping the seed in at the prescribed depth, and then pressing the soil back into place. This technique is ideal for native grasses because it plants all of the seeds at a uniform seed depth (Morgan 1997). Native grass seeds should be planted at a maximum depth of $1 / 4$ in. $(0.6 \mathrm{~cm})$. The presence of some seeds on the soil surface is acceptable; these superficial seeds, however, are more exposed to the elements and have a greater chance of drying out and dying. A shallow planting depth helps keep the seeds moist and protects them from wind and erosion, improving germination rates.

Forbs with large seeds can be planted using a no-till drill. Examples include lance-leaf coreopsis (Coreopsis lanceolata) and purple coneflower (Echinacea purpurea). Forbs with small seeds, such as black-eyed Susan (Rudbeckia hirta), can be broadcast to prevent all the seed from being deposited in a limited area.

Because fewer seeds will die from desiccation, erosion, and foraging wildlife, seeding rates are lowest when using a no-till drill (versus other methods), which reduces seed costs. No-till drills also have an advantage in reducing erosion potential because very little soil is disturbed in the process, which is especially useful when overseeding an existing grass area (Packard 1997).

During the early stages of the native grass program on the ORR (2002), a no-till drill was purchased for use by the TWRA. This drill is primarily used on the ORR but could be used by TWRA to assist landowners and land managers in the region to plant native grasses. The drill is a Great Plains model that plants an $8 \mathrm{ft}(2.4 \mathrm{~m})$ swath and requires a tractor with at least 50 to $55 \mathrm{hp}$ if there is any slope to the site. The drill has three seed boxes and can plant a range of seed sizes at the same time.

\section{A.3.2 HYDRO-SEEDING}

This method of grass planting has become popular in recent years because of its ease of operation and high rate of success (Morgan 1997). Basically, the process involves mixing seed; some type of mulch, carrier, or straw; and water to form a slurry that can then be pumped out at high pressure to coat an area. Care must be taken in creating the slurry to avoid using acidic carriers or tackifiers that might impair germination of the native grass seed. Hydro-seeding is the preferred method for planting on steep slopes and other hard-to-reach areas that cannot be seeded using a drill (Morgan 1997).

There are several drawbacks to hydro-seeding native grasses, including the following:

- Seed desiccation -With hydro-seeding all of the seeds are sprayed on top of the soil. While the slurry mixture can help retain moisture, an extended dry spell will lead to extensive seed losses. Thus, proper timing of planting is crucial. If a dry spell does occur immediately after hydro-seeding, irrigation will be necessary to stem seed losses.

- Higher seeding rate-To achieve even moderate success, hydro-seeding requires a much higher seeding rate than does drilling, which can significantly increase planting costs.

Despite its drawbacks, hydro-seeding is an option for planting native grasses on the ORR, particularly in areas that have rugged terrain or steep slopes and would otherwise be difficult to plant using a no-till drill. 


\section{A.3.3 BROADCAST SEEDING}

Broadcast seeding generally refers to spreading seeds on top of the seedbed. Broadcasting can be as simple as spreading seeds by hand out of a seed bag. Alternatively, seeds can be broadcast using conventional and/or specialized native grass equipment. Broadcasting usually requires about $25 \%$ more seed to get results similar to those achieved using a drill.

When broadcasting, seeds should be mixed with an equivalent amount of carrier. A carrier bulks up the seed, making it easier to spread. It also helps delineate areas that have been seeded (because without them many forb seeds are so small that they "disappear" immediately after hitting the soil surface) (Morgan 1997). Potential carriers include peat moss, vermiculite, and low-nitrogen fertilizer. Once all of the seed has been broadcast, the site should immediately be cultipacked or rolled to improve the seed-to-soil contact. Covering the seeds with chopped straw after planting (as with hydro-seeding) helps mulch the soil and protects the seeds from wind, erosion, and desiccation.

A major drawback to broadcast seeding is the amount of labor involved. (Straw mulching is particularly labor-intensive if a blower is not used.) Broadcasting is not recommended for sites larger than 2 acres (0.8 ha). Even then, a large number of helpers and volunteers will be needed to expeditiously seed a large area by broadcasting.

Many native wildflowers and forbs can be broadcast with conventional cyclone seeders (Morgan 1997). Special native grass broadcast seeders (such as those made by the Truax Company, Inc.) work well for fluffy native grass seeds. These seeders have "pickers" (like the ones in native grass drills) designed to capture the fluffy seeds. The ORR native grass program purchased a native grass broadcaster that rests on the applicator's shoulders and can be used for small areas. Three-point hitch cyclone seeders can also be used to broadcast fluffy grass seeds (Morgan 1997).

\section{A.3.4 PLUG PLANTING}

Planting plugs of native grasses or wildflowers is another technique for native planting (Schramm 1997). Native grass plugs tend to transplant well, and planting seedlings gives the plants a head start on weedy competitors. The use of plugs can be very beneficial in areas that have been partially restored, where powered equipment cannot enter, or where disturbance of surface soil could be problematic (e.g., in a stream riparian zone). There are a number of reasons, however, why plugs are rarely used for large plantings such as those being considered for the ORR. First, it takes time, money, and space to grow the plugs from seeds. Second, it takes a large amount of labor to plant plugs compared to seeding, especially over a large area. Third, planted plugs must be tended more carefully than seeds. Transplanted seedlings are prone to stress and shock; as a result, adequate moisture is essential. Whereas seeds might be able to withstand some level of dry conditions, plugs must receive water in the days following transplantation.

\section{A.4 SEEDS: SPECIES SELECTION, ACQUISITION, AND PREPARATION}

Choosing which species to plant can be the most exciting and creative part of the planting process because it involves deciding what the native plant stand will look like. Included in this section are a number of topics related to native grass and wildflower seeds, including species selection, stratification, seeding rate, and use of local genotypes.

\section{A.4.1 RECOMMENDED SEED MIXES}

Any number of possible grass and/or wildflower mixes can be generated for use on the ORR. Most major seed suppliers package groups of seed based on projected use, soil type, and desired appearance. Further, 
TWRA has designed mixes that it uses in wildlife management. Previously, mixes were compiled that would be suitable for enhancing wildlife, reducing erosion, or improving aesthetics. All of the wildflower and forb species in those mixes are native to either Roane or Anderson County or both according to the Atlas of Tennessee Vascular Plants (Chester et al. 1993; Chester, Wofford, and Kral 1997). Several of these mixes were planted in demonstration areas on the ORR as part of the initial phases of the program. However, in most cases the appropriate mix will depend on the site, cost considerations (wildflower seed can be very expensive), and available seed. In designing seed mixes, it is important to get the right proportion of forbs and grasses (Diboll 1997). If there are too few forb seeds, then grasses will dominate, and if there are too few grass seeds, then invasive weeds could become a problem. Generally a 50-50 mix will generate the most diverse community. Care should be taken to ensure that species chosen are native to this area. Inclusion of nonnative species is often a drawback to prepackaged mixtures from seed suppliers, although most will modify the mix if requested. The list of flora found on the ORR would be a good place from which to determine these natives. In some situations, such as for haying or biofuel operations, it might be desirable to plant a single species. Most often, however, a seed mixture is planted, yielding a diversity of foods and habitats for wildlife (Diboll 1997).

The most frequent mixes used on the ORR to date have been Mix 1A (supplied by Sharp Brothers Seed Company), a short-grass mix provided by TWRA (supplied by Bambert Seed Company), and ORNL mix used in some areas of the facility. We have also planted custom mixes aimed at wildlife enhancement and aesthetic improvement. The species and relative proportions of each are shown in Table A.1. Another custom mix was designed for use in restoration of wetlands, retention basins, and drainage ways, where woody vegetation was not desired (Table A.2). However, suitable mixes can be designed to meet any appropriate goal, as long as the species are native. This flexibility will allow seed provided by TWRA or modifications to meet specific site requirements for a project.

Seeding rate refers to the amount of grass and wildflower seeds planted over a given area, usually 1 acre (0.4 ha). Seeding rate is a critical component of a native planting. A seeding rate that is too high will result in a poor stand because of excessive plant competition. A seeding rate that is too low could also lead to stand failure if the native plants cannot establish themselves in the face of weedy competition (Morgan 1997). The seeding rate used will depend on a number of factors - the site conditions, planting method, species planted, and goal of the planting, to name a few. Experience can be a great guide, and consequently consulting with a native grass expert about seeding rates is recommended before planting.

Given the caveats above, there are a few guidelines to follow (Morgan 1997; Diboll 1997; Kurtz 2001). One, seeding rate is generally increased for broadcast and hydro-seed plantings as opposed to drilling. Two, seeding rate is also increased for dormant season plantings as opposed to spring plantings. Three, general recommendations are 4 to $6 \mathrm{lb} /$ acre $(4.5$ to $6.8 \mathrm{~kg} / \mathrm{ha})$ for wildlife plantings, 6 to $8 \mathrm{lb} / \mathrm{acre}(6.8$ to $9 \mathrm{~kg} / \mathrm{ha}$ ) for forage, and 8 to $10 \mathrm{lb} /$ acre $(9$ to $11.4 \mathrm{~kg} / \mathrm{ha}$ ) for critical areas. Seeding rate is one factor of many that will help determine the success of a native planting. Rarely, however, does seeding rate seem to be the main reason for stand failure, unless an excessively high or low seeding rate was used. Because it is not possible to know if the seeding rate was correct until after the native grass becomes established, it is best to select a rate that seems logical based on the published recommendations and adjust future plantings based on the outcome. 
Table A.1. Native warm-season grass and wildflower mixes used on the ORR (\% each species) and nominal planting rate (pure live seed per acre)

\begin{tabular}{|c|c|c|c|c|c|}
\hline Plant name & Mix 1A & $\begin{array}{c}\text { Short } \\
\text { mix }\end{array}$ & $\begin{array}{c}\text { ORNL } \\
\text { mix }\end{array}$ & $\begin{array}{c}\text { Wildlife } \\
\text { mix }\end{array}$ & $\begin{array}{c}\text { Aesthetics } \\
\text { mix }\end{array}$ \\
\hline Planting rate, pure live seed, lb/acre $(\mathrm{kg} / \mathrm{ha})$ & $\begin{array}{l}6.5 \\
(7.4)\end{array}$ & $\begin{array}{c}5.5 \\
(6.2)\end{array}$ & $\begin{array}{c}12.0 \\
(13.6)\end{array}$ & $\begin{array}{c}9.0 \\
(10.2)\end{array}$ & $\begin{array}{c}10.0 \\
(11.4)\end{array}$ \\
\hline \multicolumn{6}{|c|}{ Grasses } \\
\hline Big bluestem (Andropogon gerardii) & 28.0 & - & - & 17.0 & 5.0 \\
\hline Little bluestem (Schizachyrium scoparium) & 23.0 & 55.0 & 68.0 & 22.0 & 29.0 \\
\hline Indian grass (Sorghastrum nutans) & 31.0 & 9.0 & - & 17.0 & 5.0 \\
\hline Switch grass (Panicum virgatum) & 3.0 & - & - & - & - \\
\hline Sideoats grama (Bouteloua curtipendula) & 7.0 & 18.0 & - & - & - \\
\hline \multicolumn{6}{|c|}{ Wildflowers/Forbs } \\
\hline Mix of unspecified flowers & 8.0 & - & - & - & - \\
\hline Illinois bundleflower (Desmanthus illinoensis) & - & 18.0 & - & - & - \\
\hline Golden ragwort (Senecio aureus) & - & - & - & - & 1.0 \\
\hline Butterflyweed (Asclepias tuberosa) & - & - & 4.0 & - & 3.0 \\
\hline Rattlesnake-master (Eryngium yuccifolium) & - & - & - & - & 4.0 \\
\hline Lance-leaf coreopsis (Coreopsis lanceolata) & - & - & - & 11.0 & 7.0 \\
\hline Gray-headed sunflower (Rudbeckia pinnata) & - & - & - & - & 4.0 \\
\hline Purple coneflower (Echinacea purpurea) & - & - & 8.0 & 17.0 & 8.0 \\
\hline Black-eyed Susan (Rudbeckia hirta) & - & - & 8.0 & 11.0 & 8.0 \\
\hline Hairy sunflower (Helianthus mollis) & - & - & - & - & 10.0 \\
\hline Dense blazing star (Liatris spicata) & - & - & 6.0 & - & 5.0 \\
\hline Showy goldenrod (Solidago speciosa) & - & - & - & - & 1.0 \\
\hline Smooth aster (Aster laevis) & - & - & 6.0 & - & 4.0 \\
\hline New England aster (A. novae-angliae) & - & - & - & - & 1.0 \\
\hline $\begin{array}{l}\text { Maximilian sunflower (Helianthus } \\
\text { maximiliani) }\end{array}$ & - & - & - & 5.0 & - \\
\hline Aromatic aster (Aster oblongifolius) & - & - & - & - & 1.0 \\
\hline
\end{tabular}


Table A.2. Wetland seed mix to use for drainage ways on ORR, with a planting rate of $20 \mathrm{lb} / \mathrm{acre}(22 \mathrm{~kg} / \mathrm{ha})$

\begin{tabular}{|c|c|c|c|c|}
\hline Common name & Scientific name & $\begin{array}{c}\text { Wetland } \\
\text { characterization }^{a}\end{array}$ & $\begin{array}{l}\text { Amount }^{a} \\
\text { (lb) }\end{array}$ & $\begin{array}{c}\operatorname{Amount}_{(\mathrm{kg})}^{b} \\
\end{array}$ \\
\hline \multicolumn{5}{|c|}{ Sedges-10\% } \\
\hline Fringed sedge & Carex crinita & $\mathrm{FacW}$ & 1.0 & 1.1 \\
\hline Fox sedge & C. vulpinoides & Obligate & 1.0 & 1.1 \\
\hline \multicolumn{5}{|c|}{ Rushes-10\% } \\
\hline Soft rush & Juncus effusus & FacW & 0.4 & 0.45 \\
\hline Path rush & J. tenuis & Fac & 0.4 & 0.45 \\
\hline Green bullrush & Scirpus atrovireus & Obligate & 0.4 & 0.45 \\
\hline Wool grass & S. cyperinus & Obligate & 0.4 & 0.45 \\
\hline Many leaved rush & S. polyphyllus & Obligate & 0.4 & 0.45 \\
\hline \multicolumn{5}{|c|}{ Grasses-70\% } \\
\hline Eastern gamma grass & Tripsacum dactyloides & Fac & 3.0 & 3.4 \\
\hline River oats & Uniola latifolia & Fac & 1.0 & 1.1 \\
\hline Riverbank rye & Elymus riparius & FacW & 6.0 & 6.7 \\
\hline Virginia wild rye & E. virginicus & Fac & 3.0 & 3.4 \\
\hline Fowl mana grass & Glyceria striata & Obligate & 1.0 & 1.1 \\
\hline \multicolumn{5}{|c|}{ Forbs-10\% } \\
\hline Pennsylvania smartweed & Polygonum pennsylvanicum & FacW & 0.4 & 0.45 \\
\hline Ironweed & Vernonia novebaracensis & Fac & 0.4 & 0.45 \\
\hline Swamp milkweed & Asclepias incarnata & Obligate & 0.4 & 0.45 \\
\hline Cardinal flower & Lobelia cardinalis & FacW & 0.4 & 0.45 \\
\hline Sweetflag & Acorus americanus & Obligate & 0.4 & 0.45 \\
\hline Total & & & 20.0 & 22.4 \\
\hline
\end{tabular}

${ }^{a}$ Obligate $=$ almost always occur only in wetlands and deepwater habitats; FacW $=$ occur more in wetlands than in uplands; Fac = nearly equally common in wetlands and uplands.

${ }^{b}$ With a planting rate of $20 \mathrm{lb} /$ acre.

${ }^{c}$ With a planting rate of $22.4 \mathrm{~kg} / \mathrm{ha}$.

\section{A.4.2 SEED STRATIFICATION}

Most native grasses and wildflowers produce seeds in the late summer and early fall, which leaves little time for seedlings to become established before the onset of winter. As a result, many species have evolved to produce seeds that overwinter in the ground before germinating in the spring. This adaptation prevents seeds from germinating before or during winter when cold temperatures would prove fatal (Steffen 1997). Seeds that are harvested in the fall for later planting do not undergo this in-ground process of breaking dormancy and can remain dormant after planting. Switch grass, in particular, is well known for high seed dormancy rates.

As mentioned earlier, seed dormancy is not an issue for fall plantings because seeds will undergo the natural overwintering process. Even an early spring planting will often result in lower rates of continued seed dormancy. Spring and early summer plantings, however, are vulnerable to high dormancy rates. A popular method of overcoming this obstacle is to order seeds ahead of time and subject them to a period 
of artificial stratification. By doing so, the seeds are exposed to a pseudo-winter. The most common stratification practice is to mix equal parts of seed and either sand, peat, or vermiculite in a plastic bag. Moisten the mixture (but the mixture should not be wet because too much moisture can lead to harmful fungal growth), seal the bag, and place it in a refrigerator for 1 to 2 months prior to planting. This is usually sufficient to break dormancy in the seed and will lead to higher germination rates as compared to planting without stratification (Steffen 1997).

The main disadvantage of so-called "cold" stratification is the extra labor involved, as well as the necessity of planning far enough ahead to have the seeds long before they are to be planted. The main advantage, again, is higher germination rates. Other than that, when conducting spring or summer plantings, ORR land managers might find it desirable to experiment with seed stratification and compare the resulting germination rates with those of unstratified seed.

\section{A.4.3 LOCAL GENOTYPE SEEDS}

A number of native grass and wildflower species are found on the ORR. These plants are adapted to local conditions and have locally adapted genotypes. The same cannot be said for seeds purchased from commercial native-plant vendors. Many of these seed vendors are located in the Midwest (because there are no large-scale, native-grass commercial seed vendors in Tennessee), and their seeds come from plants adapted to conditions in that part of the country or, at best, are varieties appropriate for the ORR but grown and harvested in the Midwest. So while the grass and wildflower species are native to the ORR, the particular genotypes of the seeds are not. This situation poses a biological dilemma for conservationminded land managers. The concern over introducing nonlocal genotypes and the potential for them to dilute local genotypes is a real one (Packard and Ross 1997; Kurtz 2001) and must be kept in perspective on the ORR.

The amount of seeds required to plant the large areas that are proposed in this document necessitate purchases from commercial seed vendors. The large number of growing seasons that would be needed to collect this amount of seeds from extant native grasses and wildflowers renders such a plan impractical for the ORR. The National Park Service has implemented just such a local-genotypes-only plan at the Great Smoky Mountains National Park (GSMNP) and is growing single-species stands from seeds collected in the park. These stands will serve as seed sources for the plots to be planted in Cades Cove in the future.

The situation at the GSMNP differs from that on the ORR, however. Given that they manage a national park world-renowned for its biodiversity, the natural resource managers at the GSMNP have a mandate to retain and promote that biodiversity. Despite the high level of biodiversity found on the ORR, no similar mandate exists for its land managers. Also, previous native grass seeding has occurred on the ORR, so it is not certain that seeds collected locally actually evolved on the ORR. These facts coupled with a desire to establish native grass and forb stands quickly (despite collecting seeds for a number of years, mixed species plots have yet to be seeded at the GSMNP) diminish the appeal of using local genotypes. The amount of time, money, and labor and the space that would be needed to implement a local-genotypesonly plan on the ORR would be prohibitive (as opposed to the situation at the GSMNP, where biodiversity protection is one of the budget priorities).

In summary, although using local genotypes is the most desirable way to plant native grasses and wildflowers, it is not practical for the ORR. Forgoing local genotypes is a sacrifice that must be made if native grasses and wildflowers are to be planted expeditiously on the ORR. Preservation and promotion of local genotypes of native grasses is, however, a long-term goal of the land managers of the ORR. The two native species that have the largest populations on the ORR are little bluestem and big bluestem. For the most part, they are found on remnant cedar barrens. (For a representative population, see the little 
bluestem at Raccoon Creek Barren.) These local genotypes can be protected by planting commercial seed in areas located away from the barrens and enhancing protection of these natural areas on the ORR.

\section{A.4.4 ACQUIRING NATIVE GRASS AND WILDFLOWER SEEDS}

There are a number of ways to acquire native grass and wildflower seed for planting on the ORR (Apfelbaum et al. 1997; Clinebell 1997). Each method has its pros and cons, but in the end, it is likely that much of the seed that is planted on the ORR in the foreseeable future will have to be obtained from commercial seed vendors.

Seed quality is an essential component of achieving success with a native planting (Apfelbaum et al. 1997). Planting seeds that are contaminated with weed seeds, chaff, or a high proportion of dormant or nongerminating seeds can undermine a stand before it even gets started. Seed purchased from vendors can be of highly variable quality because there are no uniform procedures for cleaning, preparing, and storing seed (Diboll 1997). To avoid purchasing inferior seeds, it is best to stick with well-known, established seed vendors who guarantee the quality of their seeds and have a long history of shipping high-quality seeds. Because native grass seeds can be of such variable quality when harvested on a large-scale, commercial basis, the seeds are purchased and packaged according to a standard known as pure live seed (PLS). This standard takes into account the purity of the seed being sent (Diboll 1997). Factors that detract from the purity of seed include seeds of other species and inert material (e.g., stems, leaves). Germination rates (tested in a lab) are also factored into the PLS calculations. Essentially, selling seeds by PLS prevents situations such as a customer ordering $1 \mathrm{lb}$ of seed only to discover that $1 / 2 \mathrm{lb}$ of the material is seed of high quality, $1 / 4 \mathrm{lb}$ pound is chaff, and the remaining $1 / 4 \mathrm{lb}$ is non-germinating seed. When selling by PLS, vendors test their seed quality so that when $1 \mathrm{lb}$ of seed is purchased, the actual amount of material sent can be adjusted for quality (i.e., the customer might receive $1.25 \mathrm{lb}$ of material when ordering $1 \mathrm{lb}$ of seed). Therefore, native grass seeds should always be purchased on the basis of PLS.

\section{A.5 REFERENCES}

Apfelbaum, S. I., B. J. Bader, F. Faessler, and D. Mahler. 1997. “Obtaining and Processing Seeds.” In The Tallgrass Restoration Handbook: For Prairies, Savannas, and Woodlands, 99-126. Washington DC: Island Press.

Chester, E. W., B. E. Wofford, and R. Kral. 1997. Atlas of Tennessee Vascular Plants. Vol. 2. Angiosperms: Dicots. Misc. Publications No. 13, Center for Field Biology, Austin Peay State University, Clarksville, TN.

Chester, E. W., B. E. Wofford, R. Kral, H. R. DeSelm, and A. M. Evans. 1993. Atlas of Tennessee Vascular Plants. Vol. 1. Pteridophytes, Gymnosperms, Angiosperms: Monocots. Misc. Publications No. 9, Center for Field Biology, Austin Peay State University, Clarksville, TN.

Clinebell, R. R. 1997. “Tips for Gathering Individual Species.” In The Tallgrass Restoration Handbook: For Prairies, Savannas, and Woodlands, 127-132. Washington, DC: Island Press.

Diboll, N. 1997. “Designing Seed Mixes.” In The Tallgrass Restoration Handbook: For Prairies, Savannas, and Woodlands, 135-149. Washington, DC: Island Press.

Kline, V. M. 1997. "Orchards of Oak and Seas of Grass.” In The Tallgrass Restoration Handbook: For Prairies, Savannas, and Woodlands, 3-22. Washington, DC: Island Press. 
Kurtz, C. 2001. A Practical Guide to Prairie Reconstruction. Iowa City: University of Iowa Press.

Morgan, J. P. 1997. "Plowing and Seeding." In The Tallgrass Restoration Handbook: For Prairies, Savannas, and Woodlands, 193-216. Washington, DC: Island Press.

Packard, S. 1997. "Interseeding." In The Tallgrass Restoration Handbook: For Prairies, Savannas, and Woodlands, 163-192. Washington, DC: Island Press.

Packard, S., and L. M. Ross. 1997. "Restoring Remnants.” In The Tallgrass Restoration Handbook: For Prairies, Savannas, and Woodlands, 63-88. Washington, DC: Island Press.

Schramm, P. 1997. "Hand-Planted Prairies." In The Tallgrass Restoration Handbook: For Prairies, Savannas, and Woodlands, 217-222. Washington, DC: Island Press.

Steffen, J. F. 1997. "Seed Treatment and Propagation Methods." In The Tallgrass Restoration Handbook: For Prairies, Savannas, and Woodlands, 151-162. Washington, DC: Island Press. 

APPENDIX B. MAINTENANCE OF NATIVE WARM-SEASON GRASSLANDS 



\section{B.1 INTRODUCTION}

Once the native plant seeds are in the ground, a new chapter begins in the native plant restoration effort. Maintaining native plant communities is an ongoing process that can be quite intensive, particularly during the establishment years. One of the main benefits of planting native grasses, however, is the reduced investment in time and money that is required to maintain a stand over the long term (EPA 1997). After the second year, an established stand should require only infrequent attention, particularly if prescribed burns are used.

Maintenance of native plantings can require the following activities: mowing, burning, herbicide application, and irrigation. The actions land managers choose to pursue will be largely determined by siteand planting-specific goals and characteristics. The long-term goal of the planting is a critical issue when thinking about future maintenance activities. For example, if the goal of a planting is erosion control, maintenance beyond year three might not even be necessary if the succession of woody species is not undesirable. Alternatively, if a healthy native grass and wildflower community well into the future is the goal, more intense maintenance activities will be required to prevent succession.

Site- and stand-specific characteristics are critical factors in determining the necessary maintenance actions. Two examples are (1) if a planting is followed by a prolonged drought period, irrigation might be required, and (2) different herbicides might be necessary on different sites, depending on the weed species present. The methods used and the intensity needed to control weeds after planting will depend on the type and amount of weeds that infiltrate a particular site.

Many native plantings have failed because they were not properly maintained after seeding. The alarming number and variety of exotic invasive plant species present on the ORR mean that a native grass stand that is not maintained can be quickly decimated by invasive weeds. Land managers cannot afford to spend thousands of dollars on site preparation and seed mixes only to watch native stands fail to establish. The following sections contain an overview of short- and long-term maintenance activities and how they can be used here on the ORR to ensure the success of native grass and wildflower plantings.

\section{B.2 IRRIGATION}

As mentioned earlier, native plants are generally drought-tolerant. The seeds of some native plants, however, could have difficulty surviving a prolonged period with no rain. Planting is optimally carried out in the late spring to take advantage of seasonal rains. In the event of a dry period, however, irrigation might help prevent mass desiccation of seeds (Morgan 1997). Timely watering can keep seeds sufficiently moist and save the planting from a preventable failure.

Some published literature recommends watering during the first 4 to 6 weeks after planting to maximize seedling survival and germination (Shirley 1994). Obstacles to irrigating include making the required monetary and labor investments, locating the necessary equipment, and finding an appropriate water source.

If an untimely drought should occur immediately after planting and it is determined that irrigation is necessary (and the logistics are worked out), a couple of simple guidelines should be followed. Watering should be done in the early morning, to avoid both wasting water (associated with high levels of evaporation during the hotter part of the day) and increased threat of fungal growth on seeds (associated with late afternoon/evening watering). Care must be taken to prevent overwatering - the seeds only need to be kept moist. Brief but frequent irrigation is recommended, and it should be discontinued 6 weeks after planting at the latest. 


\section{B.3 MAINTENANCE IN THE FIRST AND SECOND YEARS: WEED CONTROL}

During the first growing season, a restored plot will probably not leave land managers overly impressed. Most of the native grasses will display nothing but a single, straight leaf above ground until late in the summer. Any annuals that were planted, such as black-eyed Susan, will compete for dominance with weeds. Because the native grasses and some wildflowers are not well represented above ground during the first growing season, they are vulnerable to shading and nutrient and moisture competition from fastgrowing weeds (Shirley 1994). Beating back weeds in a native planting is an iterative process that requires great attention during the first 2 years after planting. Controlling weeds until the native plants are firmly established is essential to the success of a native planting.

The two main management tools for controlling weeds during the first and second years of a native planting are herbicide applications and mowing (Shirley 1994). If less is done of one, more must usually be done of the other. Some people favor mowing, some prefer using herbicides. For example, some landowners do not mow their plots in the spring of the second year, preferring instead to blanket-spray an herbicide to control weeds and woody species later in the growing season. Again, only experience can help determine the best methods of controlling weeds in a native planting. What works well on one plot might not be as successful in another. Most often, if herbicides and mowing are used in tandem at the right times, weeds will be effectively controlled.

\section{B.3.1 HERBICIDE APPLICATION}

In the months immediately following planting, herbicides are highly effective at killing weedy competition. Herbicides can help provide a brief weed-free period that allows native plants to become established (Kurtz 2001). Glyphosate herbicides are not an option after planting because they will kill native grasses and forbs along with weeds. For postplanting applications, the herbicide Plateau ${ }^{\circledR}$ is often used (Kurtz 2001). This relatively new herbicide was formulated by American Cyanamid (now a subsidiary of BASF) specifically for use with prairie grass species. Most prairie grass species, and many forbs, are labeled for use within certain spraying limits. The exception is switch grass, which will often be killed by Plateau applications (Kurtz 2001).

The Plateau product label, along with native plant experts experienced with the herbicide, recommends applying a blanket spraying of Plateau either before seedling emergence or after the seedlings have reached the five-leaf stage. (Depending on the amount of competition in the first year, two applications of Plateau could be necessary.) Young seedlings are more susceptible to the herbicide's harmful effects. The spraying rate will vary depending on the amount of competition (see label), but rates should be kept as low as possible (i.e., 4 to $6 \mathrm{oz} / \mathrm{acre}$ [292 to $438 \mathrm{~mL} / \mathrm{ha}$ ]) to protect switch grass and any susceptible forbs. The Plateau label provides recommended spraying rates and a list of forbs that are tolerant of the herbicide.

Certain species, such as the invasive sericea lespedeza (Lespedeza cuneata), could pose particular problems on the ORR. Sericea lespedeza is a strong competitor, driving out native species in disturbed habitats, and is rarely controlled to any sufficient degree by Plateau, which is generally ineffective against legumes. Species that are not adequately controlled by Plateau might need to be spot sprayed with either Roundup; 2,4-D; or a triclopyr herbicide such as Garlon 4 ${ }^{\mathrm{TM}}$ or Remedy ${ }^{\mathrm{TM}}$. Tricoplyr-based herbicides are ideal for plantings dominated by native grasses because they do not kill grasses and are superior to Plateau in controlling broadleaf plants. (They will, however, kill any desirable forbs.)

Herbicides might be needed to control weeds throughout the life of the planting, although if all goes well, the necessity for their use will taper off after the second year. During the second growing season, blanket or spot applications can control tenacious invasive weeds and woody species, particularly if the plot is not 
mowed and/or there is a large seed bank of weed seeds (Solecki 1997; Morgan 1997). Blanket sprayings of broadleaf-controlling herbicides should be conducted in the early spring, when cool-season weeds are growing but the native grasses remain dormant. (Keep in mind, however, that native forbs might already be sprouting in early spring.) With all herbicide applications, an expert should be enlisted to help decide which herbicide(s) to use, the application rate, and the method of application.

\section{B.3.2 MOWING}

\section{B.3.2.1 First Year}

Mowing can be an effective way to control weed competition, especially if it is used in conjunction with herbicide treatments (Morgan 1997). Weed competition will be noticeably reduced (thereby reducing the need for mowing) if Plateau herbicide has been applied soon after planting. Once weeds begin to grow higher than the native plantings during the first growing season, however, mowing will help suppress the weedy species and prevent them from shading out the native plants (Kurtz 2001).

Mowing is merely a tool to ensure that the restored native grasses and wildflowers are receiving enough light. A general rule during the first growing season is to mow weeds once they reach a height of 8 to 12 in. $(20$ to $30 \mathrm{~cm})$ or whenever weeds get two to three times taller than the native plants (Kurtz 2001). Weeds should always be mowed back above the new seedlings (keeping them mowed back to 4 to 6 in. [10 to $15 \mathrm{~cm}$ ] is common). Two or more mowings (perhaps even as often as once a month) will probably be required during the first growing season. The frequency of mowing on any particular site will be entirely determined by the height and intensity of weed competition (Morgan 1997). With each successive mowing, the blade height should be raised so as not to clip the native plants. Weeds should definitely be mowed before seed set to help reduce weed populations in future years (Shirley 1994). Mowing should be discontinued late in the season; the remaining growth will help insulate the young plants over the winter.

If cutting is done with a rotary mower, mowing should be more frequent so as to reduce the amount of weeds falling on the native plants. Excessive amounts of cuttings covering native plants can smother the seedlings. For this reason, a flail-type mower is recommended because it chops up the weeds so they dry out quickly (Shirley 1994).

\section{B.3.2.2 Second Year}

Weeds will continue to plague restored stands into the second growing season. Although a spring burning is not recommended until the third year after a planting (to allow for a sufficient accumulation of fuel), mowing will continue to be an effective management tool. Most often, the stand is mowed low in early spring of the second year (Shirley 1994; Kurtz 2001). An early spring (late March or early April) mowing has three main benefits:

1. The previous year's growth is removed, exposing the soil surface to the warming rays of the sun. Earlier soil warming generally increases growth, flowering, and seed set of native grasses and forbs.

2. Cool-season weeds that get a head start on native plants are significantly undermined.

3. The prime egg-laying season (May to June) for ground-nesting birds is avoided.

The key to spring mowing is raking the resultant clippings off the plot. Leaving the clippings on the plot will prevent the soil from warming and smother the native plants. As stated above, using a flail-type mower is preferable to one with a simple rotary blade. 
Additional mowing for competition control might be necessary during the second growing season if weeds persist in shading out the native plants. A stand should never be mowed lower than 8 in. $(20 \mathrm{~cm})$ once the native plants have reached this height. Also, a stand should be mowed as late into the summer as possible to avoid disturbing bird nests (Byre 1997).

\section{B.4 LONG-TERM MAINTENANCE IN THIRD YEAR AND BEYOND}

Nursing a native grass and wildflower stand to establishment takes much attention and patience. The first year or two can be all work and little reward. Once a native grass and wildflower stand has been established, however, the benefits to wildlife, forage (for livestock), and aesthetics become apparent while the workload eases considerably. If prescribed burns are an option, then one maintenance activity every 3 to 5 years might be all that is necessary (Pauly 1997). The use of alternative maintenance methods, including mowing and herbicide application, will require more attention. The following sections discuss methods for maintaining a native grass and wildflower stand from year three into the future.

\section{B.4.1 MOWING, HAYING, AND HERBICIDE APPLICATIONS}

Prescribed burns are the preferred long-term management tool for native grasses. If prescribed burns are not a viable option for a given native grass stand, however, a program of mowing, haying, and herbicide applications can mimic some (but not all) of the effects of a prescribed burn (Kurtz 2001; Morgan 1997; Packard and Ross 1997). Depending on the status of the stand, one or more of these maintenance activities might be necessary to maximize the health of the grasses and wildflowers.

Early spring mowing should commence in the second year and then be repeated in following years as necessary. An early spring mowing will control the cool-season grasses that are already growing vigorously, while not harming the native grasses that are just coming up (should be 1 in. [2.5 $\mathrm{cm}]$ or less). The mower blade should be set close to the ground (Kurtz 2001).

Spring mowing will reduce litter (provided the clippings are raked) by removing the previous year's growth and will also help keep cool-season weeds in check (Shirley 1994). By reducing litter, mowing also exposes the soil to full sun, allowing early warming that will encourage the growth of the native warm-season grasses at the expense of cool-season weeds. A stand should not be mowed if the native grasses and forbs have already reached $1 \mathrm{ft}(30.5 \mathrm{~cm})$ in height because doing so could damage the native plants.

Again, mowing will not provide all of the benefits that come with prescribed burns, such as nutrient recycling, plant-density reduction, and hardwood-competition control. Only using a mowing rotation will lead to reduced stand health over time (Packard and Ross 1997). However, two key factors in the longterm management of native grasses — soil warming and competition control—are adequately addressed by mowing, and thus, a stand should be mowed if prescribed burns are not an option.

Herbicide applications might be necessary to control some competition that is not sufficiently addressed by mowing. Plateau, a triclopyr-based herbicide for spot-application of broadleaves, can be used for blanket spraying (again, check label for susceptible forbs) (Kurtz 2001). Woody competitors, which pose the greatest problems in a stand that is never burned, will require some herbicide treatment. Although the seedlings can be continually mowed back, the roots continue to grow, and a large stump could form over time.

Some published material asserts that a stand must be hayed instead of mowed in lieu of burning. Presumably, haying has a similar effect to mowing and raking off the resultant litter. A haying rotation of 
once every 2 years is recommended for Eastern states, where trees tend to come in and up very quickly (Solecki 1997).

\section{B.4.2 PRESCRIBED BURNS}

Native grasslands evolved under a periodic fire regime (Kline 1997). Fire suppression programs in this century have been one factor leading to the widespread decrease of grassland ecosystems in the United States (Packard and Mutel 1997; Pauly 1997). As a result of the historic association between warm-season grasses and fire, prescribed burns are the most cost-efficient and effective management tool for native grass stands over the long-term. This section is not intended to provide technical information on how to conduct a prescribed burn; fire experts can supply that information. This section is intended to describe the benefits of prescribed burns, compare the effectiveness of burns with other management techniques, and provide basic guidelines for considering a prescribed burn.

Prescribed burns are generally carried out every 3 to 5 years in a native grass stand, beginning in the third year when enough litter has accumulated (Pauly 1997). More frequent burns might be necessary if coolseason and woody competition are particularly intense. There are numerous reasons why prescribed burns are the preferred management method for restored native grass stands (Pauly 1997; Shirley 1994):

- One of the main benefits of prescribed burns is litter removal. After 3 to 5 years of stand growth, plant density might increase to the point at which it becomes difficult for wildlife to move, forage, and nest. Stand health can decrease as density increases.

- Controlled burning increases microbial activity in the soil, which in turn leads to an increase in nutrient recycling and availability for plant growth.

- Just as with mowing, burning exposes the soil to the sun, leading to early soil warming that encourages the growth of warm-season grasses at the expense of cool-season weeds.

- Forsaking prescribed burns can lead to unintended stand dominance by grasses at the expense of desired wildflowers.

- Burning stimulates increased native plant productivity, flowering, and seed germination.

- Unlike mowing, burning wipes the stand clean, killing weedy and woody competition. Mowing will not effectively kill woody vegetation and cool-season weeds, but merely knock them back. Therefore, a mowing regime used as an alternative to burning will allow stand density to increase annually. Allowing tree roots and stumps to continue growing can result in serious problems in the future.

Again, a combination of mowing, herbicide applications, and haying can mimic some of the benefits of burning, but over time, the health of unburned stands decreases, while burned stands become healthier. The physiological benefits of fire cannot be matched using any other method.

Prescribed burns should be conducted after cool-season competition has started growing in earnest, but before native plants have devoted much energy to aboveground growth (i.e., when they are about 1 in. $[2.5 \mathrm{~cm}]$ tall). Such burns control the weeds and give the native plants a competitive advantage (Shirley 1994; Pauly 1997). In the Southeast, vegetation comes up early and quickly, making a late spring burn difficult (Pauly 1997). Burns should be conducted any time after February 15 until the native grasses have broken dormancy (i.e., are 1 in. [2.5 cm] tall or less) sometime in March. Anything later could result in damage to desirable native plants. Just as a small window exists for dormant-season plantings, a month and a half or less is a relatively small window in which to schedule a prescribed burn. Burn crews must be 
at the ready for signs of a day with ideal burning conditions. Weather in February and March is notoriously unpredictable and may not afford many good days to burn, so crews must be ready to burn on February 15 to maximize the days on which they will be able to burn.

Soil erosion is of little concern with mature stands because the native plants will have established massive root systems. Erosion is more of a concern with young stands, but it becomes less of a worry with burns conducted in March. The closer the burn is to the subsequent green-up, the less potential there is for soil erosion.

Another advantage to burning so early is that there will be no impact on ground-nesting birds, which can be a concern for late spring burns (Byre 1997). In addition, wildflowers that start growing early in the spring are spared by a burn in February or March (Pauly 1997). The weather in February and March can be very safe for burning, a factor that would be undeniably important on the ORR.

One factor that must always be considered, no matter the timing of the burn, is soil dryness. Burning on dry soil can cause irreparable damage to desirable native grasses and wildflowers (Pauly 1997). Many experts recommend forgoing prescribed burns in years after a drought. Burning in winter or early spring leads to significant reductions in soil moisture as compared to late spring burnings (Pauly 1997), which makes careful consideration of soil moisture that much more critical in Tennessee.

In an ideal situation, only one-third of the total native grass acreage would be burned at any one time. This approach keeps stands in various stages of post-burn succession, yielding maximum benefits to wildlife (Shirley 1994). However, it would mean burning some portion of native grasses each year, which might not be cost effective for the ORR. In addition, the initial demonstration plots are relatively small, making subdivision for burning less practical.

It is possible that prescribed burning of restored stands might not be allowed on the ORR, and some areas could not be burned regardless of any considerations. These areas include those close to buildings, utilities (e.g., power and gas lines), and contaminated areas. Whenever burning is not an option, a mow/hay/herbicide long-term maintenance plan should be put into place to mimic the effects of burning as much as possible.

\section{B.5 REFERENCES}

Byre, V. J. 1997. “Birds.” In The Tallgrass Restoration Handbook: For Prairies, Savannas, and Woodlands, 327-338. Washington, DC: Island Press.

Environmental Protection Agency (EPA). 1997. A Source Book on Natural Landscaping for Public Officials. Environmental Protection Agency, Washington, DC. http://www.epa.gov/glnpo/ greenacres/toolkit/index.html.

Kline, V. M. 1997. "Orchards of Oak and Seas of Grass.” In The Tallgrass Restoration Handbook: For Prairies, Savannas, and Woodlands, 3-22. Washington, DC: Island Press.

Kurtz, C. 2001. A Practical Guide to Prairie Reconstruction. Iowa City: University of Iowa Press.

Morgan, J. P. 1997. "Plowing and Seeding." In The Tallgrass Restoration Handbook: For Prairies, Savannas, and Woodlands, 193-216. Washington, DC: Island Press.

Packard, S., and C. F. Mutel. 1997. "Perspective." In The Tallgrass Restoration Handbook: For Prairies, Savannas, and Woodlands, xix-xxviii. Washington, DC: Island Press. 
Packard, S., and L. M. Ross. 1997. "Restoring Remnants." In The Tallgrass Restoration Handbook: For Prairies, Savannas, and Woodlands, 63-88. Washington, DC: Island Press.

Pauly, W. R. 1997. “Conducting Burns.” In The Tallgrass Restoration Handbook: For Prairies, Savannas, and Woodlands, 223-244. Washington, DC: Island Press.

Shirley, S. 1994. Restoring the Tallgrass Prairie. Iowa City: University of Iowa Press.

Solecki, M. K. 1997. "Controlling Invasive Plants.” In The Tallgrass Restoration Handbook: For Prairies, Savannas, and Woodlands, 251-278. Washington, DC: Island Press. 

APPENDIX C. COMMON WARM-SEASON NATIVE GRASSES 



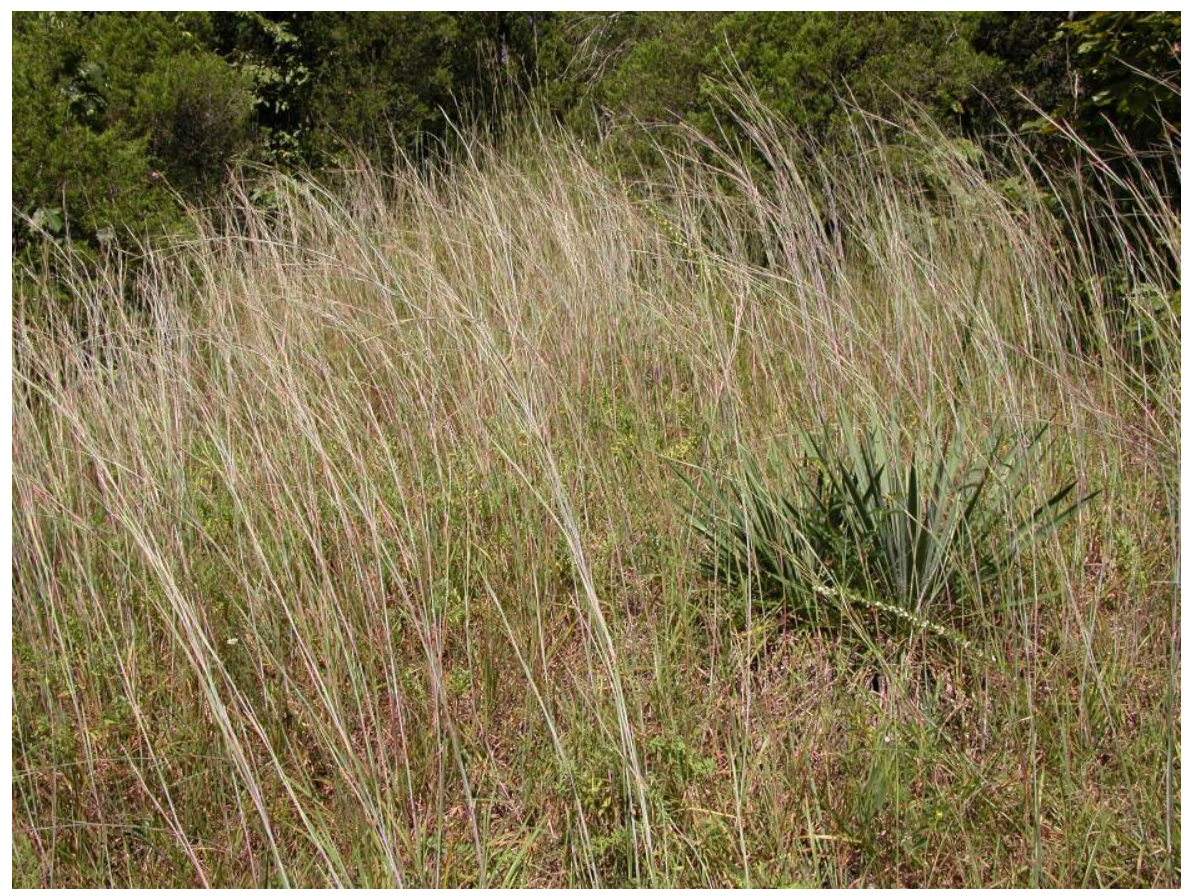

Fig. C.1. Big bluestem (Andropogon gerardii) in a cedar barren habitat.

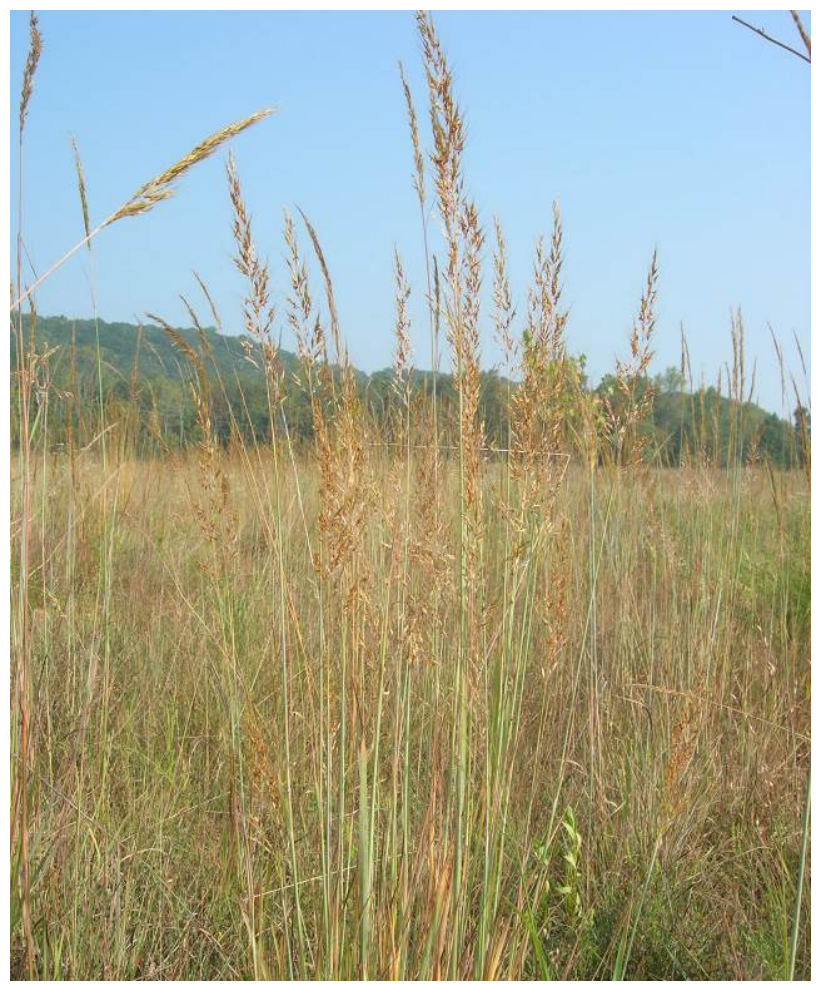

Fig. C.2. Indian grass (Sorghastrum nutans) showing seed heads. 


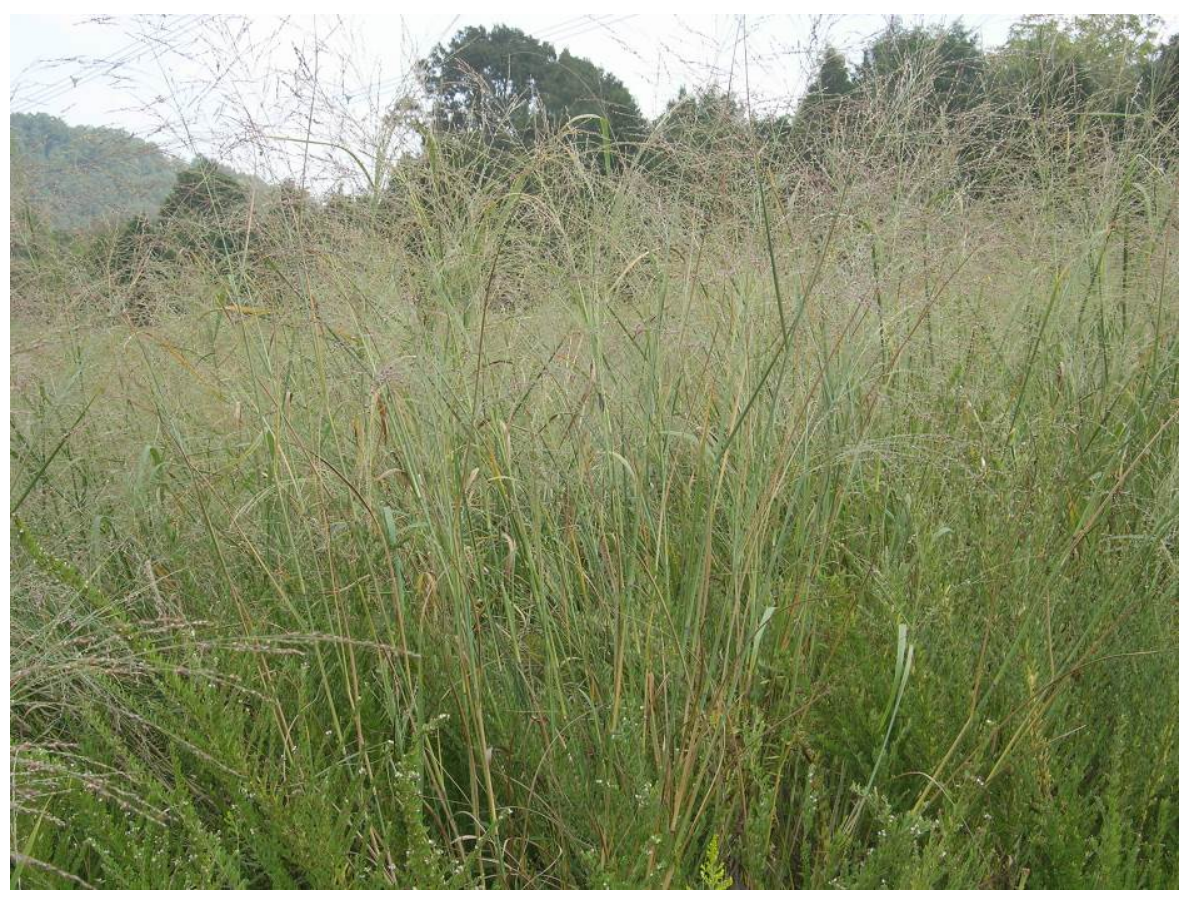

Fig. C.3. Switch grass (Pancium virgatum) showing seed heads.

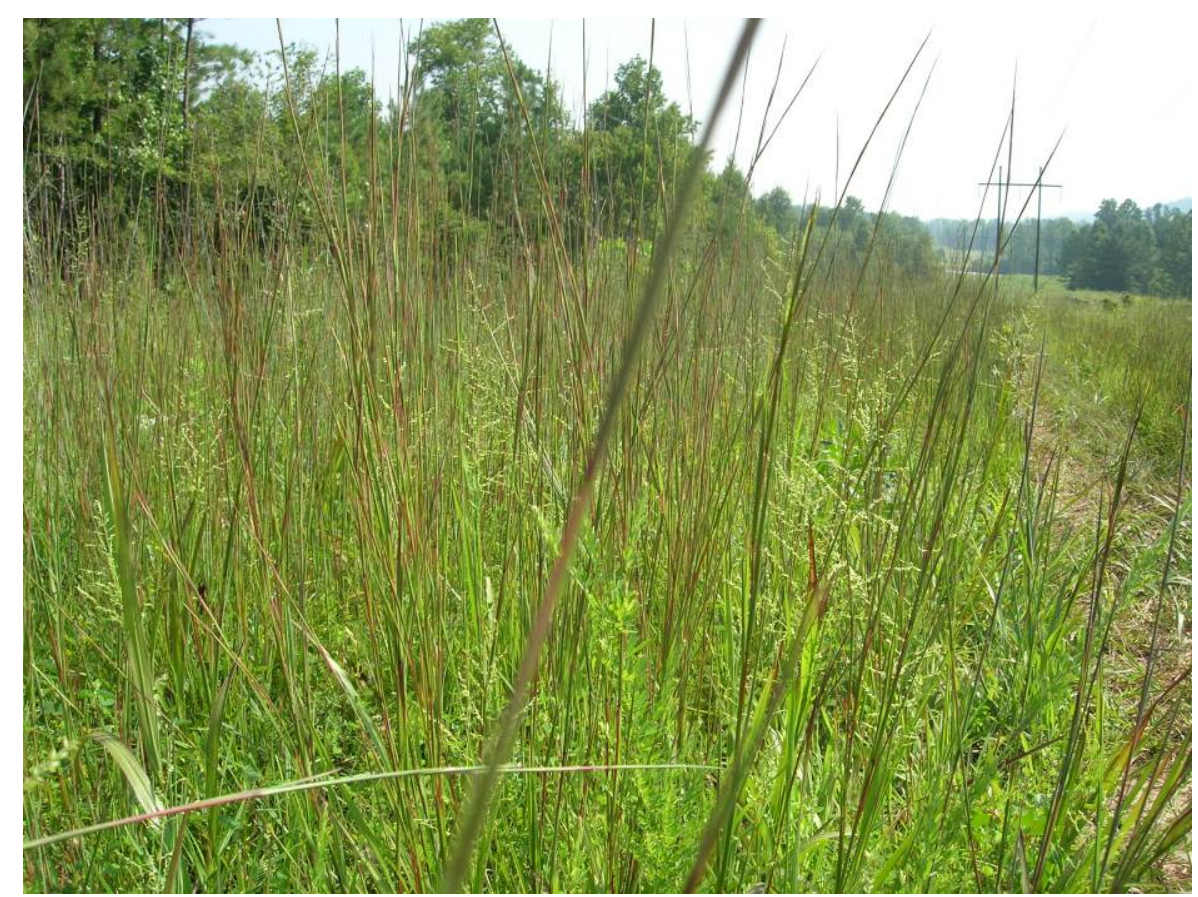

Fig. C.4. Little bluestem (Schizachyrium scoparium) along a power line right-of-way. 
APPENDIX D. EXAMPLES OF GRASSLANDS ON THE ORR 



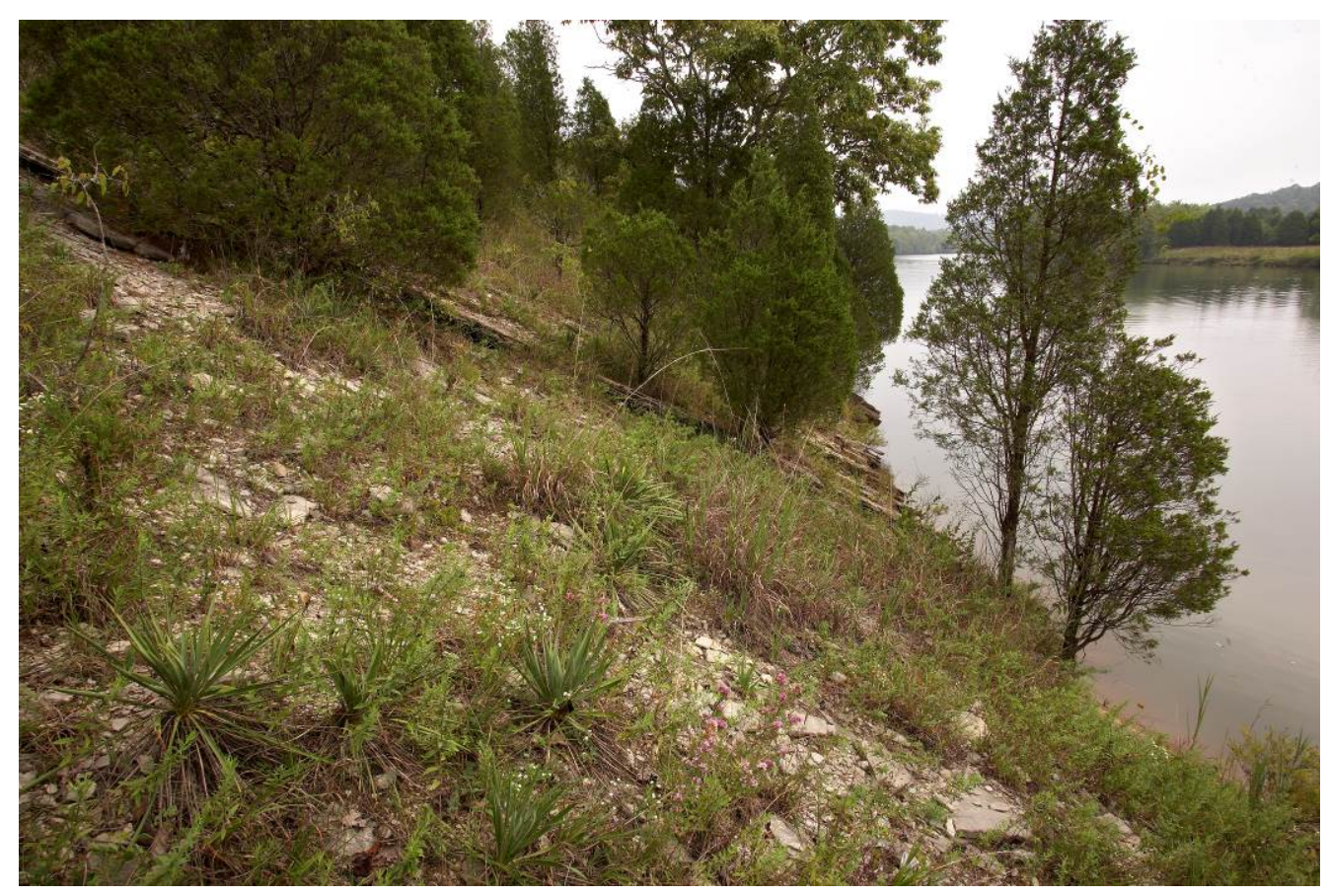

Fig. D.1. Raccoon Creek Barren.

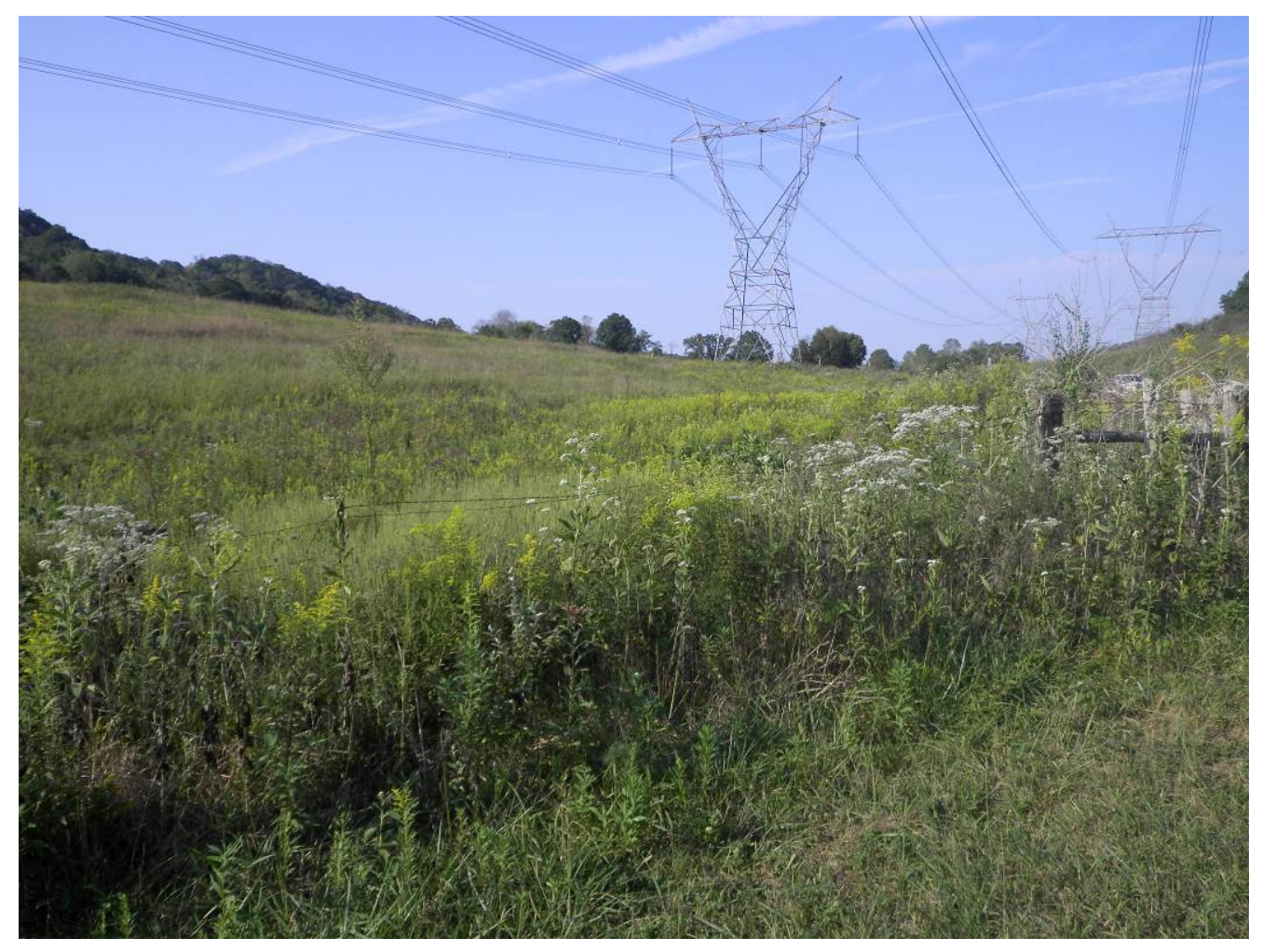

Fig. D.2. Powerline right-of-way at Freels Bend. 


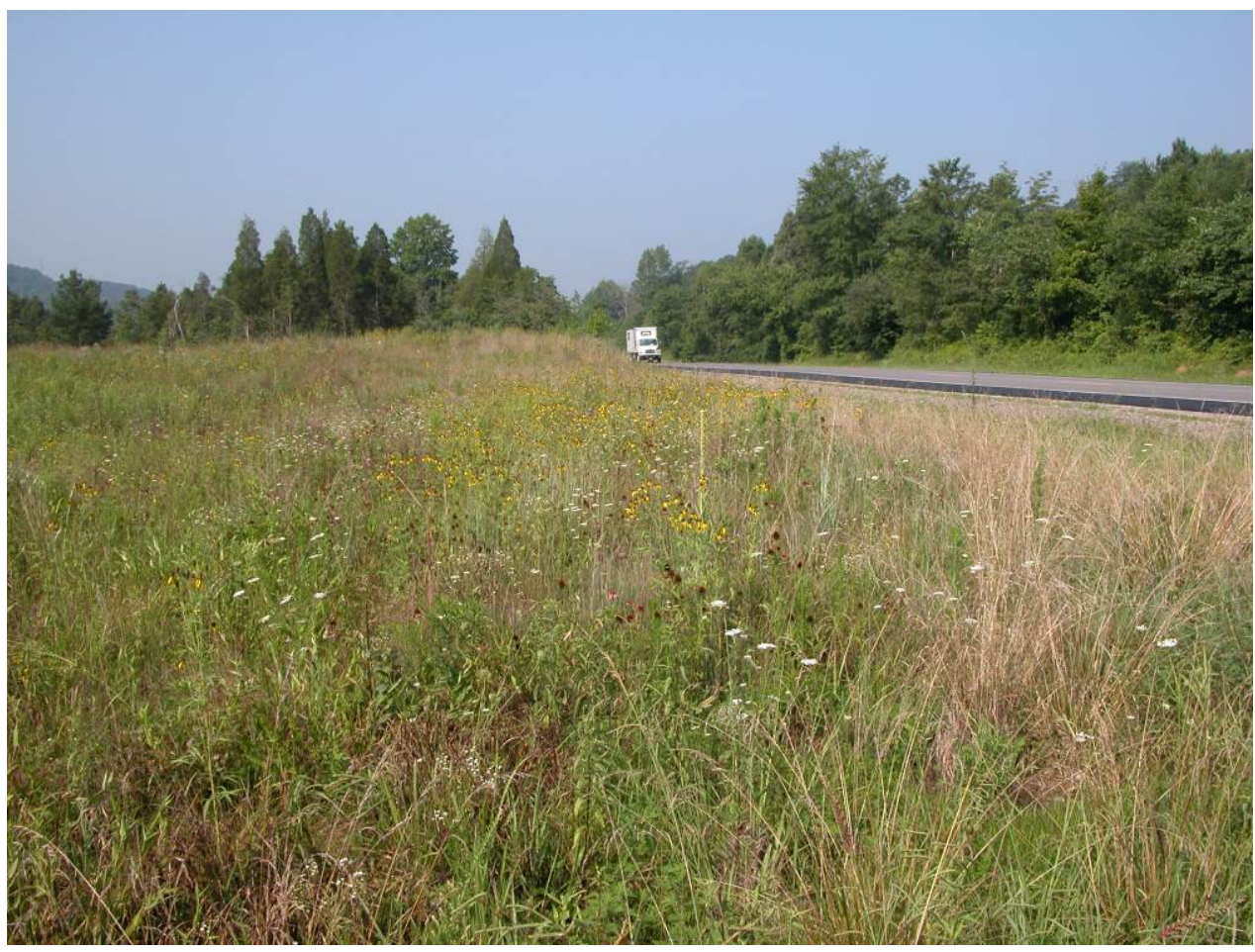

Fig. D.3. Grasslands along Bethel Valley Road.

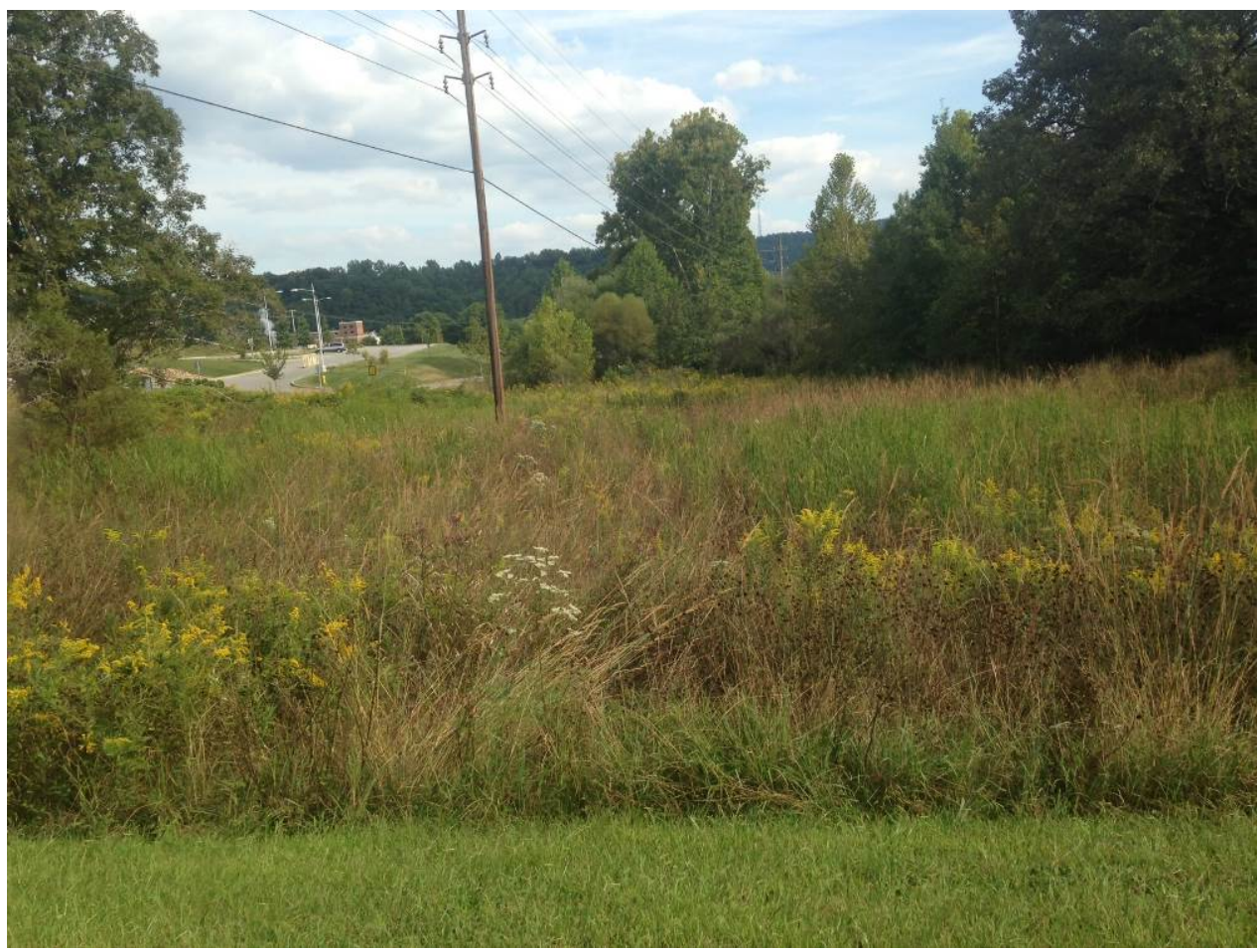

Fig. D.4. Grassland riparian buffer zone on ORNL campus. 